\title{
Crystallographic and docking (Cathepsins B, K, L and S) studies on bioactive halotelluroxetanes
}

\author{
Ignez Caracelli, ${ }^{, I}$ Stella H. Maganhi, ${ }^{\text {II }}$ Josiane de Oliveira Cardoso, ${ }^{\text {I }}$ Rodrigo L. O. R. Cunha, ${ }^{\text {III }}$ Mauricio Angel Vega- \\ Teijido, ${ }^{\ddagger}$ IV Julio Zukerman-Schpector ${ }^{\mathrm{IV}}$ and Edward R. T. Tiekink ${ }^{*}, \mathrm{~V}$ \\ I BioMat, Departamento de Física, Universidade Federal de São Carlos, C.P. 676, São Carlos, SP, 13565-905, Brazil \\ II BioMat, Programa de Pós-graduação em Biotecnologia, Universidade Federal de São Carlos, C.P. 676, São Carlos, SP, 13565-905, Brazil \\ ${ }^{\text {III }}$ Center of Natural Sciences and Humanities, Federal University of ABC, Santo André, São Paulo 09210-180, Brazil \\ ${ }^{\text {IV }}$ Laboratório de Cristalografia, Estereodinâmica e Modelagem Molecular, Departamento de Química, Universidade Federal de São Carlos, C.P. \\ 676, São Carlos, SP, 13565-905, Brazil
}

${ }^{\mathrm{v}}$ Research Centre for Crystalline Materials, School of Science and Technology, Sunway University, 47500 Bandar Sunway, Selangor Darul Ehsan, Malaysia

Received; accepted

Keywords: Halotelluroxetanes / DFT / docking in Cathepsins / crystal structure analysis / X-ray diffraction
Abstract. The molecular structures of the halotelluroxetanes p- $\mathrm{MeOC}_{6} \mathrm{H}_{4} \mathrm{Te}(\mathrm{X})\left[\mathrm{C}\left(=\mathrm{C}(\mathrm{H}) \mathrm{X}^{\prime}\right) \mathrm{C}\left(\mathrm{CH}_{2}\right)_{\mathrm{n}} \mathrm{O}\right], X=X^{\prime}=\mathrm{Cl}$ and $\mathrm{n}=6(\mathbf{1})$ and $X=$ $\mathrm{Cl}, X^{\prime}=\mathrm{Br}$ and $\mathrm{n}=5$ (4), show similar binuclear aggregates sustained by $\{\cdots \mathrm{Te}-\mathrm{O}\}_{2}$ cores comprising covalent $\mathrm{Te}-\mathrm{O}$ and secondary Te $\cdots \mathrm{O}$ interac- tions. The resulting $\mathrm{C}_{2} \mathrm{ClO}_{2}$ (lone-pair) sets define pseudo-octahedral ge- ometries. In each structure, $\mathrm{C}-\mathrm{X} \cdots \pi$ (arene) interactions lead to supramo- lecular layers. Literature studies have shown these and related compounds (i.e. 2: $X=X^{\prime}=\mathrm{Cl}$ and $\mathrm{n}=5 ; 3: X=X^{\prime}=\mathrm{Br}$ and $\mathrm{n}=5$ ) to inhibit Cathepsins $\mathrm{B}, \mathrm{K}, \mathrm{L}$ and $\mathrm{S}$ to varying extents. Molecular docking calculations have been conducted on ligands (i.e. cations derived by removal of the tellurium- bound $X$ atoms) $\mathbf{1}^{\prime}-\mathbf{3}^{\prime}$ (note $\mathbf{3}^{\prime}=\mathbf{4}^{\prime}$ ) enabling correlations between affinity for sub-sites and inhibition. The common feature of all docked complexes was the formation of a Te-S covalent bond with cysteine residues, the rel- ative stability of the ligands with an E-configuration and the formation of a $\mathrm{C}-\mathrm{O} \cdots \pi$ interaction with the phenyl ring; for $\mathbf{1}^{\prime}$ the $\mathrm{Te}-\mathrm{S}$ covalent bond was weak, a result correlating with its low inhibition profile. At the next level differences are apparent, especially with respect to the interactions formed by the organic-ligand-bound halides. While these atoms do not

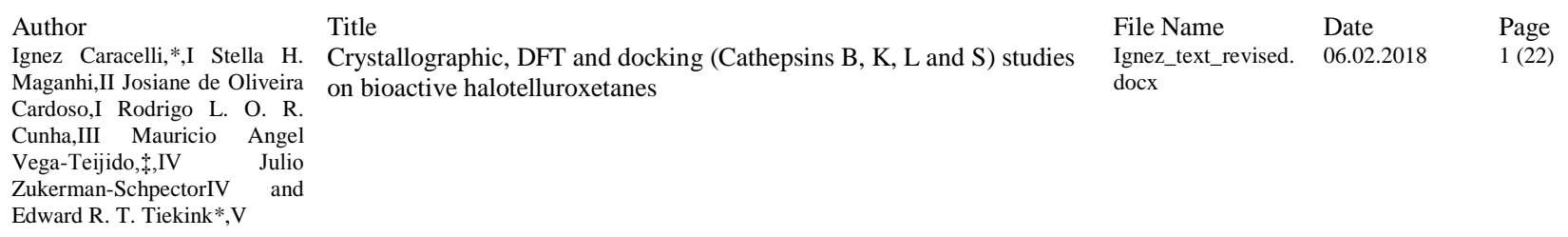


form specific interactions in Cathepsins $\mathrm{B}$ and $\mathrm{K}$, in Cathepsin L, these halides are involved in $\mathrm{C}-\mathrm{O} \cdots \mathrm{X}$ halogen bonds.

*Correspondence authors: ignez@df.ufscar.br (I.C.); edwardt@ sunway.edu.my

(E.R.T.T.)

* Present address: Computational Chemistry and Biology Group-CCBG, DETEMA, Facultad de Química-Universidad de la República, CC1157 Montevideo Uruguay

\section{Introduction}

Since the discovery of selenium as a component of glutathione peroxidase $[1,2]$ and of the $21^{\text {st }}$ amino acid, selenocysteine [3, 4], selenium compounds have been increasingly investigated as potential therapeutic agents against a range of diseases [5-10]. Due to the chemical similarities to tellurium, selenium's heavier congener, tellurium compounds have also attracted interest in the pharmaceutical context $[11,12]$. Thus, tellurium compounds have shown promise since they are an immunomodulator in organisms [13] and display anti-oxidant [14-16], anti-parasitic [17, 18] and anti-inflammatory [19] activities, are known to be neuroprotective [20,21] and have potential to be developed as anti-cancer agents [22-24]. The most notable tellurium compound that exerts biological activity is found in the salt ammonium trichlorido (dioxyethylene-O,O')tellurate, known as AS-101 (Figure 1a) [25]. This low-molecular weight organotellurate is a potent immunomodulator [26] that has been in clinical trials for psoriasis [27], topical treatment for human papillomavirus [28], prevention of infertility in chemotherapy patients [29] and for inhibition of angiogenesis [24, 30].
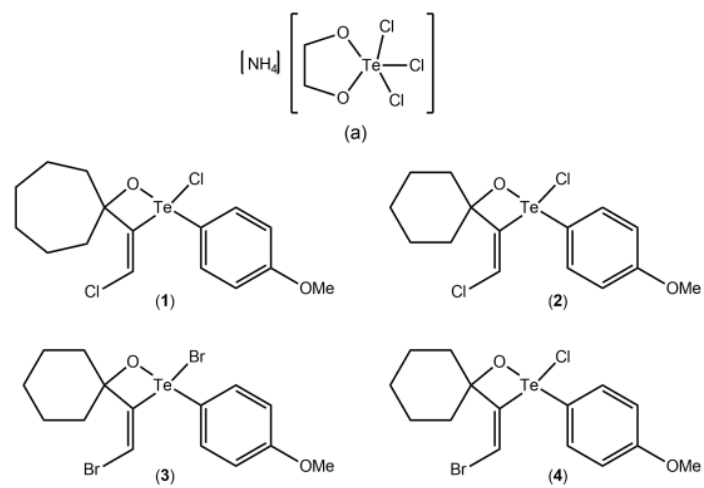

Fig. 1: Chemical diagrams of (a) ammonium trichlorido (dioxoethylene-O,O')tellurate (AS-101) and (b) (3E)-2-chloro-3-(chloromethylidene)-2-(4-methoxyphenyl)-1-oxa-2 $\lambda^{4}$-telluraspiro-[3.6]decane (1), (3E)-2-chloro-3-(chloromethylidene)-2-(4-methoxyphenyl)-1-oxa-2 $\lambda^{4}$-telluraspiro[3.5]nonane (2), and analogues of (2): the Te-bound bromido/methylidene-bromo species $(\mathbf{3})$ and the mixed Tebound chlorido/methylidene-bromo species (4).

Research on this non-toxic compound shows the cation to be a specific covalent inhibitor of cysteine proteases such as papain and Cathepsin B [26]. These observations have encouraged further studies of tellurium-

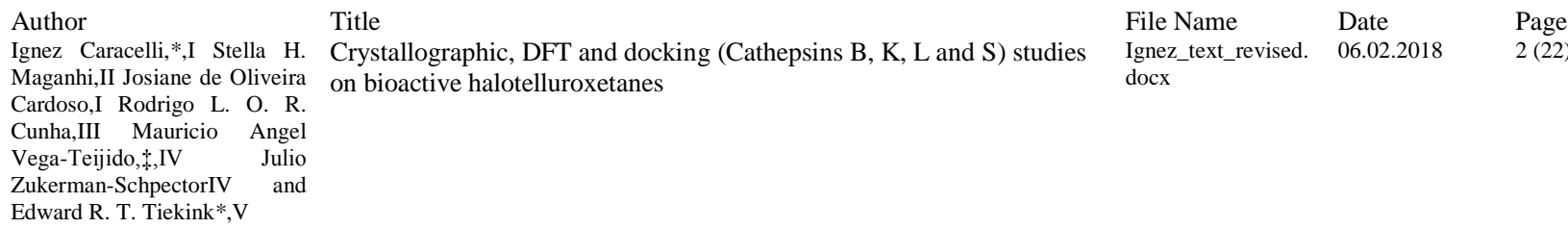


based compounds as inhibitors of this class of enzyme. In this context, Cunha and co-workers have presented series of organotellurium compounds that show irreversible inhibitory activity greater than AS-101 against Cathepsin B as well as being irreversible inhibitors against Cathepsins $\mathrm{K}, \mathrm{L}$ and $\mathrm{S}[31,32]$.

The inhibition of cysteine protease by tellurium compounds is due to a substitution reaction that follows the removal of a labile group bound to tellurium leading to the formation of a covalent $\mathrm{Te}-\mathrm{S}$ bond with the thiolate-S atom of a Cys 29 residue, i.e. Te-SG $[33,34]$. The difference in Cathepsin inhibition values exhibited by the same compound arise owing to specific features of the various sub-sites in the enzyme which are responsible for the specificity of the protease $[35,36]$. Thus, in order to design a powerful and specific Cathepsin inhibitor, it is of fundamental importance to have detailed knowledge of the features of each sub-site of each Cathep$\sin$ [37-39]. In addition, it is worth highlighting that this class of enzyme is related to several pathological processes such as osteoporosis (Cathepsin K) [40, 41], neurodegenerative disease (Cathepsin D) [42] and metastasis in several types of cancer (Cathepsins B, K, L and S) [43-45]. Hence, Cathepsins are promising targets for the treatment of such disorders [46].

With the aim to understand how potential therapeutic agents based on tellurium inhibit cysteine proteases, significant effort has been made to elucidate their binding modes and correlate them with inhibitory data [47-51]. Continuing this research, the present work targets to explain trends in previous published inhibitory data of a series of halotelluroxetanes, Figure 1, against Cathepsins B, K, L and S. New crystallographic data are presented for $\mathbf{1}$ and 4, Figure 1, and docking studies of cationic ligands 1'-4', i.e. species corresponding to 1-4 but with a tellurium-bound halide removed, with the above-mentioned proteases. Moreover, to more fully understand the structural relationships between Cathepsins B, K, L and S, a sequential and structural alignment of these has been made using a molecular visualisation program.

\section{Experimental}

\section{Synthesis and crystal growth}

Compounds 1-4 were prepared as previously described [52]. In a typical reaction, a solution of the 3 -hydroxy alkyne $(11 \mathrm{mmol})$ in dry benzene (10 $\mathrm{mL}$ ) was added to a suspension of $p$-methoxyphenyltellurium trichloride/bromide $(10 \mathrm{mmol})$ in dry benzene $(40 \mathrm{~mL})$. The reaction mixture was refluxed for $8 \mathrm{~h}$, during which the $p$-methoxyphenyltellurium trichloride was consumed, forming a clear, yellow solution. The resulting solution was cooled to room temperature, diluted with ethyl acetate and washed with a saturated $\mathrm{NH}_{4} \mathrm{Cl}$ solution and brine. The solvent was evaporated under reduced pressure and the residue was quickly chromatographed on $\mathrm{SiO}_{2}$, using $\mathrm{CCl}_{4}$ and $\mathrm{CHCl}_{3} / \mathrm{MeOH}$ (5:1) as eluents. The resulting oils that were isolated after chromatography were recrystallised from $\mathrm{CH}_{2} \mathrm{Cl}_{2}$ for $\mathbf{1}$ and $\mathrm{CHCl}_{3} /$ hexane for $\mathbf{2}$ and $\mathbf{4}$ to yield crystals suitable for X-ray analysis. The structure of $\mathbf{2}$ has already been described [52].

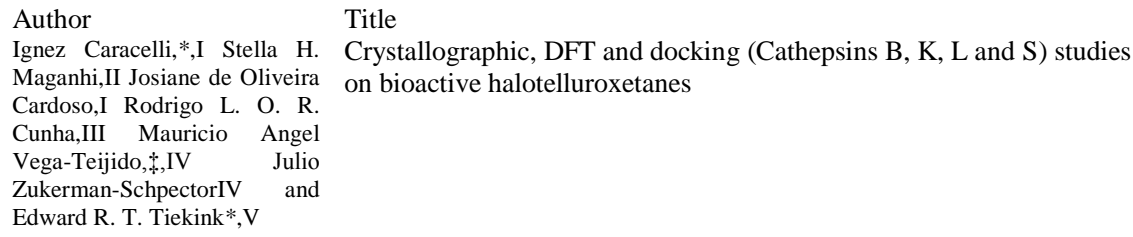

$\begin{array}{lll}\text { File Name } & \text { Date } & \text { Page } \\ \text { Ignez_text_revised. } & 06.02 .2018 & 3(22)\end{array}$ $\operatorname{docx}$ 


\section{Crystal structure determination}

Intensity data for $\mathbf{1}$ and $\mathbf{4}$ were measured at $293 \mathrm{~K}$ on an Enraf Nonius TurboCAD4 diffractometer using graphite-monochromatised MoK $\alpha$ radiation $(\lambda=0.71073 \AA)$. Data processing and absorption corrections ( $\psi$-scans) were accomplished with CAD4 Express [53] and XCAD4 [54]. Unit cell data, X-ray data collection parameters, and details of the structure refinement are given in Table 1. The structures were solved by Direct Methods using SIR92 [55] and full-matrix least-squares [56] refinement was on $F^{2}$ (anisotropic displacement parameters and $\mathrm{C}$-bound $\mathrm{H}$ atoms in their idealised positions). A weighting scheme of the form $w=1 /\left[\sigma^{2}\left(F_{\mathrm{o}}^{2}\right)+(a P)^{2}+\right.$ $b P]$ where $P=\left(F_{\mathrm{o}}{ }^{2}+2 F_{\mathrm{c}}{ }^{2}\right) / 3$ was introduced. The programs WinGX [57], PLATON [58], ORTEP-3 for Windows [57] and DIAMOND [59] were also used in the study.

Tab: 1. Crystallographic data and refinement details for $\mathbf{1}$ and $\mathbf{4} .^{l}$

\begin{tabular}{|c|c|c|}
\hline & 1 & 4 \\
\hline Formula & $\mathrm{C}_{16} \mathrm{H}_{20} \mathrm{Cl}_{2} \mathrm{O}_{2} \mathrm{Te}$ & $\mathrm{C}_{15} \mathrm{H}_{18} \mathrm{BrClO}_{2} \mathrm{Te}$ \\
\hline Formula weight & 442.82 & 473.25 \\
\hline Crystal colour, habit & Colourless, prism & Colourless, prism \\
\hline Crystal size/mm & $0.15 \times 0.20 \times 0.30$ & $0.10 \times 0.10 \times 0.20$ \\
\hline Crystal system & monoclinic & triclinic \\
\hline Space group & $P 2_{1} / c$ & $P 1$ \\
\hline$a / \AA$ & $9.4478(8)$ & $9.2532(9)$ \\
\hline$b / \AA$ & $21.0267(10)$ & $9.9010(10)$ \\
\hline$c / \AA$ & $9.3916(7)$ & $10.1590(10)$ \\
\hline$\alpha l^{\circ}$ & 90 & $96.080(10)$ \\
\hline$\beta /^{\circ}$ & $111.622(5)$ & $92.621(9)$ \\
\hline$\gamma \gamma^{\circ}$ & 90 & $116.370(10)$ \\
\hline$V / \AA^{3}$ & $1734.4(2)$ & $824.68(16)$ \\
\hline$Z / Z^{\prime}$ & $4 / 1$ & $2 / 1$ \\
\hline$D_{\mathrm{c}} / \mathrm{g} \mathrm{cm}^{-3}$ & 1.696 & 1.906 \\
\hline$F(000)$ & 872 & 456 \\
\hline$\mu(\mathrm{MoK \alpha}) / \mathrm{mm}^{-1}$ & 2.024 & 4.386 \\
\hline Measured data & 5312 & 3503 \\
\hline$\theta$ range $/^{\circ}$ & $2.3-30.0$ & $2.5-26.3$ \\
\hline Unique data & 5040 & 3299 \\
\hline$R_{\text {int }}$ & 0.026 & 0.022 \\
\hline Observed data $(I \geq 2.0$ & 4036 & 2846 \\
\hline$R$, obs. data; all data & $0.027 ; 0.046$ & $0.023 ; 0.034$ \\
\hline$a, b$ in wghting scheme & $0.032,0.918$ & $0.034,0.418$ \\
\hline$R_{\mathrm{w}}$, obs. data; all data & $0.068,0.072$ & $0.058 ; 0.061$ \\
\hline$\Delta \rho_{\max , \min } / \mathrm{e} \AA^{-3}$ & $0.43,0.81$ & $0.32,0.50$ \\
\hline
\end{tabular}

${ }^{1}$ Supplementary Material: Crystallographic data for the structures reported in this paper have been deposited with the Cambridge Crystallographic Data Centre as supplementary publication no. CCDC-1552738 and 1552739. Copies of available material can be obtained free of charge, on application to CCDC, 12 Union Road, Cambridge CB2 1EZ, UK, (fax: +44-(0)1223-336033 or e-mail: deposit@ccdc.cam.ac.uk).

Ignez Caracelli,*,I Stella H. Crystallographic, DFT and docking (Cathepsins B, K, L and S) studies Maganhi,II Josiane de Oliveira on bioactive halotelluroxetanes Cardoso,I Rodrigo L. O. R.

Cunha,III Mauricio Angel

Vega-Teijido, \$,IV Julio

Zukerman-SchpectorIV and

Edward R. T. Tiekink*,V 


\section{Generation of ligand structures}

To generate ligand structures for the docking studies, the experimentally determined structures of $\mathbf{1}, \mathbf{2}$ and $\mathbf{4}$ were used as the starting points. The structures were made cationic by the removal of the tellurium-bound halide in each case, leading to $\mathbf{1}^{\prime}, \mathbf{2}^{\prime}$ and $\mathbf{4}^{\prime}$, respectively, meaning the cation derived from 3 is equivalent to $4^{\prime}$. Although the experimental structures uniformly have an E configuration about the exocyclic double bond, each was isomerised to have a $\mathrm{Z}$ configuration for trialling in the docking calculations. The HyperChem 8.0 program [60] was used for all manipulations with the Steepest Descent method and with a RMS gradient of $0.01 \mathrm{kcal} /$ ( $\mathrm{mol}$ ).

\section{Docking studies}

The GOLD 5.0.1 program $[61,62]$ was used with the GoldScore fitness function that takes into account factors such as hydrogen-bonding energy, van der Waals energy and ligand torsion strain.

The performed calculations were based on the formation of a covalent complex involving the cysteine residue of the catalytic sites of the Cathepsins and the tellurium atom of the telluroxetanes.

Docking simulations were carried out considering the rigid enzyme and total ligand flexibility. Only amino acid residues within a radius of $10.0 \AA$ around the ligand cavity were considered. All water molecules were removed since there are none in the active sites of the structures of the original Cathepsins and are therefore, not influential in the interactions.

$\mathrm{y}$ do not participate in the interactions between the ligand and enzyme.

The formation of a covalent bond between the sulphur atom of cysteine-reactive site SG (Cys29 in Cathepsin B and Cys25 in other Cathepsins) and the tellurium atom of each ligand was imposed. The constraint parameter of the GOLD program was employed to establish a range for the bond length between the tellurium and sulphur atom. The range used was 2.4 to $3.5 \AA$ where the ligand has the freedom to settle in the active site of the enzyme.

\section{Molecular visualization}

For molecular visualization of the poses and for the analysis of interactions and alignments, the DS Visualizer program 3.5 [63] was employed.

\section{Results}

\section{Experimental molecular structures}

The molecular structure of $\mathbf{1}$ as determined by X-ray crystallography is shown in Figure 2 and selected geometric parameters are collated in Table 2. The immediate coordination geometry of the tellurium atom is defined by a chloride anion, an oxygen and two carbon atoms. Molecules selfassemble across a centre of inversion via secondary Te $\cdots O$ interactions to form dimeric aggregates. Hence, the tellurium atom is five-coordinate within a $\mathrm{C}_{2} \mathrm{ClO}_{2}$ donor set. The stereochemically active lone-pair of electrons is projected to occupy a position approximately trans to the Te-bound aryl substituent. The central $\{\cdots \mathrm{Te}-\mathrm{O}\}_{2}$ parallelogram has quite distinct

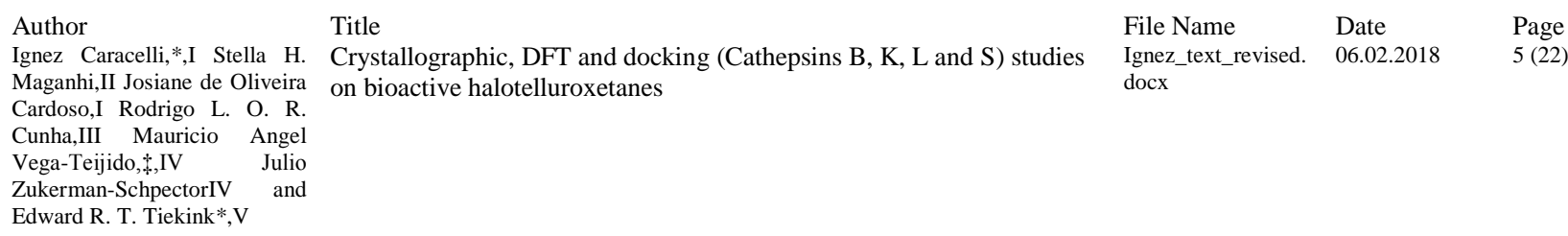


edge lengths of approximately 2.1 and $2.9 \AA$. Within the ring, short $\mathrm{O} 1 \cdots \mathrm{O} 1^{\mathrm{i}}$ contacts of $2.662(2) \AA$ are noted; symmetry operation $\mathrm{i}: 1-x,-y$, $1-z$. The configuration about the $\mathrm{C} 2=\mathrm{C} 3$ double bond is $\mathrm{E}$.

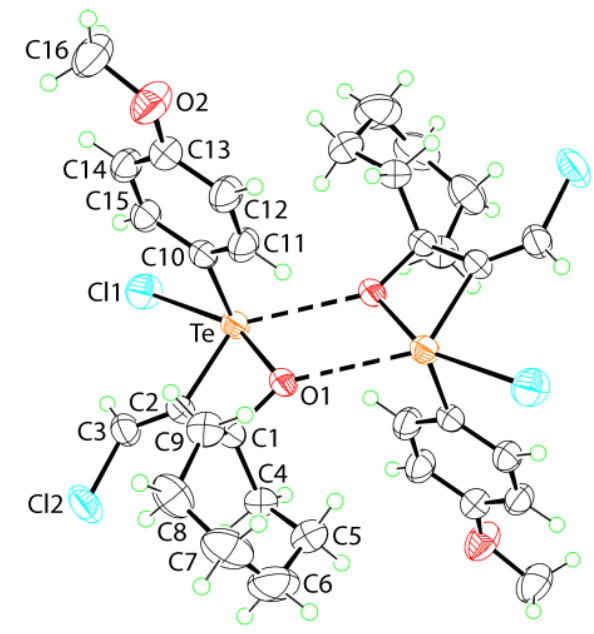

Fig. 2: Molecular structure of $\mathbf{1}$ showing atom labelling and displacement ellipsoids at the $50 \%$ probability level. Unlabelled atoms are related by the symmetry operation: $1-x,-y, 1-z$.

Tab. 2: Summary of key geometric parameters $\left(\AA{ }^{\circ}\right)$ for $\mathbf{1}$ and $\mathbf{4}^{l}$

\begin{tabular}{l|l|l}
\hline \multicolumn{1}{c|}{ Parameter } & \multicolumn{1}{|c}{$\mathbf{1} ; \mathrm{n}=10$} & \multicolumn{1}{|c}{$\mathbf{4} ; \mathrm{n}=9$} \\
\hline $\mathrm{Te}-\mathrm{C} 11$ & $2.5556(7)$ & $2.5309(9)$ \\
\hline $\mathrm{Te}-\mathrm{O} 1$ & $2.0440(17)$ & $2.0574(19)$ \\
\hline $\mathrm{Te}-\mathrm{C} 2$ & $2.110(2)$ & $2.107(3)$ \\
\hline $\mathrm{Te}-\mathrm{C}(\mathrm{n})$ & $2.128(3)$ & $2.122(3)$ \\
\hline $\mathrm{Te}-\mathrm{O} 1^{\mathrm{i}}$ & $2.9039(17)$ & $2.909(2)$ \\
\hline $\mathrm{C} 2-\mathrm{C} 3$ & $1.314(3)$ & $1.312(4)$ \\
\hline $\mathrm{C} 1-\mathrm{Te}-\mathrm{O} 1$ & $156.52(5)$ & $156.71(6)$ \\
\hline $\mathrm{C} 1-\mathrm{Te}-\mathrm{C} 2$ & $90.11(7)$ & $90.82(8)$ \\
\hline $\mathrm{C} 11-\mathrm{Te}-\mathrm{C}(\mathrm{n})$ & $91.20(7)$ & $90.62(8)$ \\
\hline $\mathrm{C} 11-\mathrm{Te}-\mathrm{O} 1^{\mathrm{i}}$ & $141.08(4)$ & $139.45(5)$ \\
\hline $\mathrm{O} 1-\mathrm{Te}-\mathrm{C} 2$ & $66.47(8)$ & $66.04(10)$ \\
\hline $\mathrm{O} 1-\mathrm{Te}-\mathrm{C}(\mathrm{n})$ & $91.64(8)$ & $91.02(10)$ \\
\hline $\mathrm{O} 1-\mathrm{Te}-\mathrm{O} 1^{\mathrm{i}}$ & $62.26(7)$ & $63.71(8)$ \\
\hline $\mathrm{C} 2-\mathrm{Te}-\mathrm{C}(\mathrm{n})$ & $100.43(9)$ & $100.22(11)$ \\
\hline $\mathrm{C} 2-\mathrm{Te}-\mathrm{O} 1^{\mathrm{i}}$ & $128.00(8)$ & $128.41(9)$ \\
\hline $\mathrm{C}(\mathrm{n})-\mathrm{Te}-\mathrm{O} 1^{\mathrm{i}}$ & $89.26(7)$ & $91.66(9)$ \\
\hline $\mathrm{Te}-\mathrm{O} 1-\mathrm{C} 1$ & $99.38(13)$ & $98.69(15)$ \\
\hline $\mathrm{Te}-\mathrm{C} 2-\mathrm{C} 1$ & $94.66(14)$ & $94.62(18)$ \\
\hline $\mathrm{Te}-\mathrm{C} 2-\mathrm{C} 3$ & $127.1(2)$ & $127.4(2)$ \\
\hline $\mathrm{O} 1-\mathrm{C} 1-\mathrm{C} 2$ & $99.35(18)$ & $100.2(2)$ \\
\hline
\end{tabular}

${ }^{1}$ Symmetry operation i: $11-x,-y, 1-z$ and $41-x, 2-y, 2-z$.

The four-membered ring comprising the Te, $\mathrm{O} 1, \mathrm{C} 1$ and $\mathrm{C} 2$ atoms is essentially planar [r.m.s. deviation $=0.0201 \AA$ ] with the deviations from

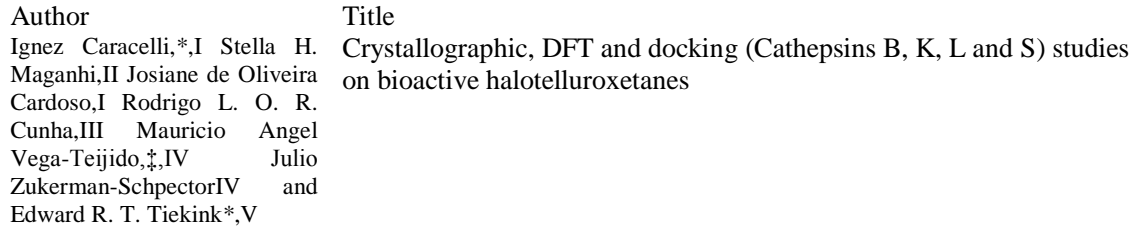

File Name Date Page Ignez_text_revised. $\quad 06.02 .2018 \quad 6(22)$ docx 
the least-squares plane being 0.0141(8), -0.0205(11), 0.0253(14) and $0.0189(10) \AA$, respectively. The seven-membered ring adopts a twisted chair conformation with the central $\mathrm{C} 1, \mathrm{C} 4, \mathrm{C} 6, \mathrm{C} 7$ and $\mathrm{C} 9$ atoms [r.m.s. deviation $=0.0820 \AA$; deviations $=-0.030(2), 0.083(2),-0.114(3), 0.104(3)$ and -0.043(2) $\AA$, respectively] defining the base with the C5 and C8 atoms lying 0.780(5) and 0.794(5) $\AA$ to either side of the base. The cycloheptane ring is twisted with respect to the 1,2-oxatelluretane ring with the dihedral angle between the best planes through each ring being $72.67(10)^{\circ}$, indicating an almost orthogonal arrangement. Indeed, the $\mathrm{C} 1$ atom lies in the plane of the oxatelluretane ring and the C6-C7 bond is bisected by the plane. The methyoxyphenyl ring lies perpendicular to the oxatelluretane ring as seen in the dihedral angle of $78.64(8)^{\circ}$.

In the molecular packing of $\mathbf{1}$, the only specific contacts between molecules within the standard distance criteria in PLATON [58] is a C$\mathrm{Cl} \cdots \pi($ arene $)$ contact, i.e. $\mathrm{C} 3-\mathrm{Cl} 2 \cdots \mathrm{Cg}(\mathrm{C} 10-\mathrm{C} 15)^{\mathrm{ii}}=3.7069(15) \AA$, $\mathrm{C} 3 \cdots \mathrm{Cg}(\mathrm{C} 10-\mathrm{C} 15)^{\mathrm{ii}}=5.199(3) \AA$ with the angle at $\mathrm{Cl} 2$ being $142.66(10)^{\circ}$ for symmetry operation ii: $2-x,-y, 2-z$. These interactions lead to supramolecular layers in the ac-plane, Figure $3 \mathrm{a}$. Within the layers, very weak $\mathrm{Te} \cdot \cdots \mathrm{Cl} 22^{\mathrm{iii}}$ contacts are noted with the separation of $3.8505(10) \AA$ being about $0.04 \AA$ greater than the sum of their van der Waals radii [58]; symmetry operation iii: $2-x,-y, 1-z$. The $\mathrm{Cl} 22^{\mathrm{iii}}$ atom approaches the tellurium centre from the unoccupied face and therefore, might be considered a weak chalcogen (secondary) bonding interaction [64]. The layers stack along the $b$-axis without directional interactions between them, Figure $3 b$.

(a)
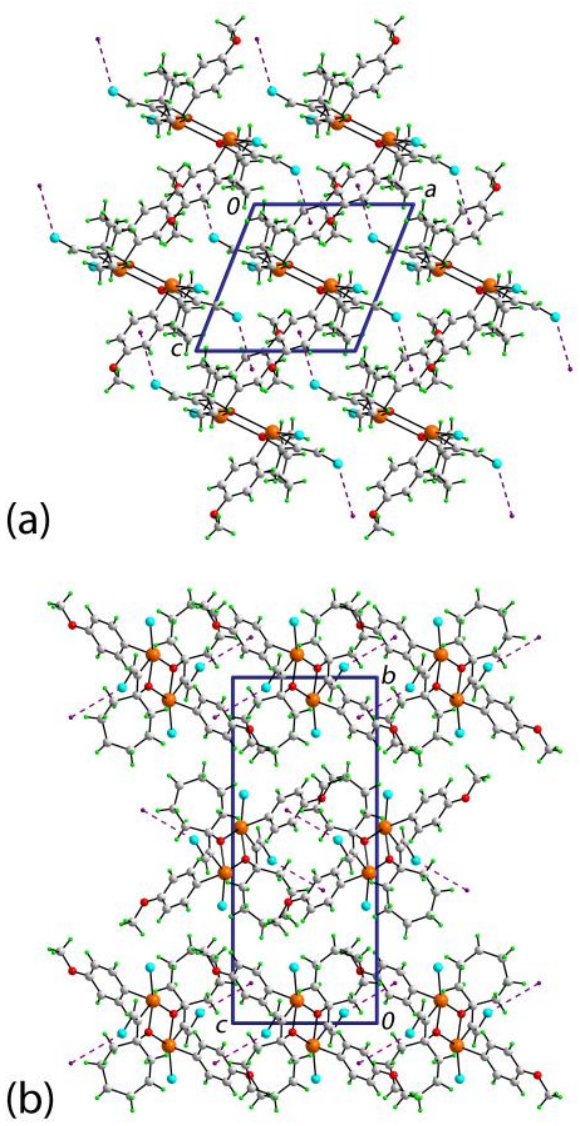

Fig. 3: Molecular packing in 1: (a) view in projection down the $b$-axis of the unit cell showing the supramolecular layer sustained by $\mathrm{C}-\mathrm{H} \cdots \mathrm{Cl}$ interactions and (b)

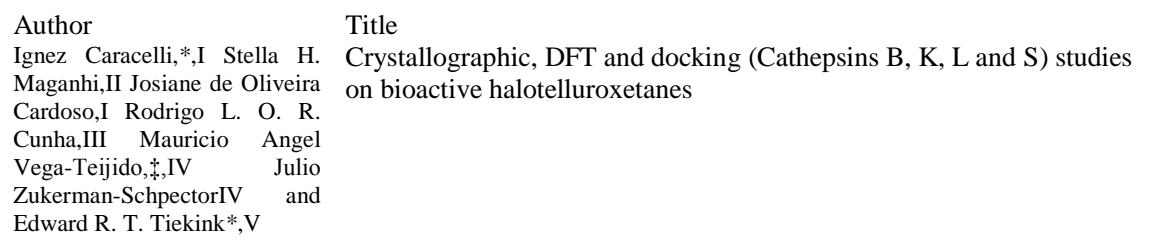


The molecular structure of $\mathbf{4}$, Figure 4, presents essentially the same features as just described for $\mathbf{1}$, despite the presence of a six-rather than a seven-membered ring, and bromide at the $\mathrm{C} 2=\mathrm{C} 3$ double bond. Thus, the formation of a centrosymmetric, dimeric aggregate mediated by secondary $\mathrm{Te} \cdot \mathrm{OO}$ interactions, the immediate tellurium atom coordination geometry and the E configuration of the double bond all persist. In terms of bond lengths, Table 2 , there is a slight reduction in the $\mathrm{Te}-\mathrm{Cl}$ bond length in $\mathbf{4}$, by about $0.025 \AA$ which appears to be compensated by a small elongation, i.e. $0.013 \AA$, in the Te-O bond. In the same way, variations in key bond angles are limited to about $2^{\circ}$ and all involve the centrosymmetrically-related $\mathrm{O} 1$ atom with the maximum difference seen in the $\mathrm{C}(\mathrm{n})-\mathrm{Te}-\mathrm{O} 1^{\mathrm{i}}$ angles, i.e. 89.26(7) and $91.66(9)^{\circ}$ for $\mathbf{1}$ and 4, respectively. It is noted that the magnitude of the secondary $\mathrm{Te} \cdot \mathrm{OO}$ interactions in both structures are equal within experimental error.

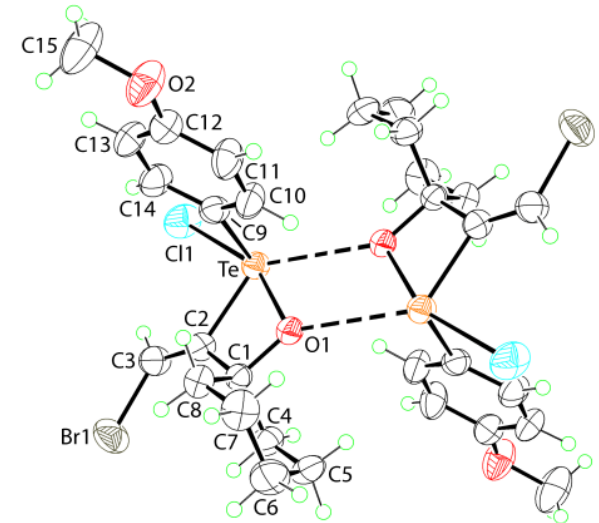

Fig. 4: Molecular structure of $\mathbf{4}$ showing atom labelling and displacement ellipsoids at the $50 \%$ probability level. Unlabelled atoms are related by the symmetry operation: $1-x, 2-y, 2-z$.

The conformational relationships within the molecule of $\mathbf{4}$ match those for 1. Thus, the oxatelluretane ring is planar [r.m.s. deviation $=0.0352 \AA$, with the deviations from the least-squares plane being -0.0242(8), 0.0357(12), -0.0446(15) and 0.0331(12) for Te, O1, C1 and C2 atoms, respectively]. The cyclohexyl ring has a chair conformation and the bestplane through this ring forms a dihedral angle of $87.98(12)^{\circ}$ with the oxatelluretane ring indicating a twisted relationship analogous to that described for 1. Finally, the oxatelluretane and methyoxyphenyl rings are perpendicular with the dihedral angle being $80.14(9)^{\circ}$.

The molecular packing of 4 exhibits $\mathrm{C}-\mathrm{Br} \cdots \pi($ arene) contacts, i.e. $\mathrm{C} 3-$ $\mathrm{Br} 1 \cdots \mathrm{Cg}(\mathrm{C} 9-\mathrm{C} 14)^{\mathrm{ii}}=3.7686(15) \AA, \mathrm{C} 3 \cdots \mathrm{Cg}(\mathrm{C} 9-\mathrm{C} 14)^{\mathrm{ii}}=5.275(4) \AA$ with the angle at $\mathrm{Br} 1$ being $135.18(12)^{\circ}$ for symmetry operation ii: $-x, 1-y, 2-z$. As shown in Figure 5a, these interactions lead to supramolecular layers in the ac-plane. Analogous to 1 , weak $\mathrm{Te} \cdot \cdots \mathrm{Br} 1{ }^{\mathrm{iii}}$ chalcogen (secondary) bonding interactions within the layers are evident with the separation being $3.9179(6) \AA$, i.e. about $0.01 \AA$ greater than the sum of their van der Waals radii [58]; symmetry operation iii: $-x, 2-y, 2-z$. The layers stack along the

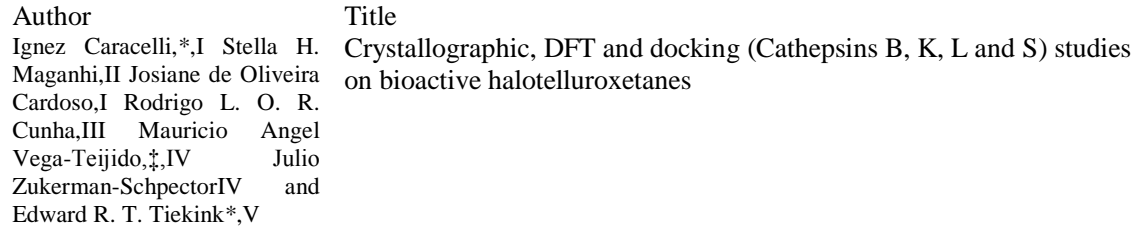


$c$-axis without directional interactions between them. While not isomorphous, $\mathbf{1}$ and $\mathbf{4}$ are close to being isostructural having very similar molecular packing.

(a)

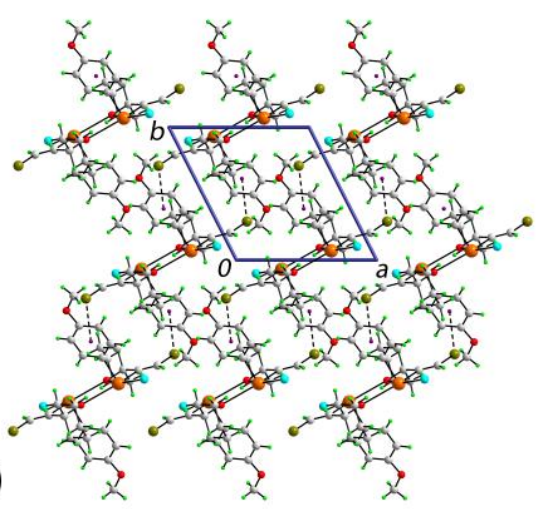

(b)

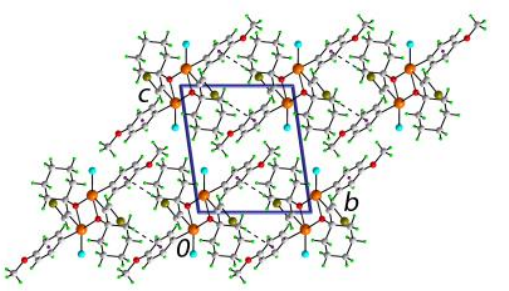

Fig. 5: Molecular packing in 4: (a) view in projection down the $c$-axis of the unit cell showing the supramolecular layer sustained by $\mathrm{C}-\mathrm{H} \cdots \mathrm{Br}$ interactions and $(\mathrm{b})$ view of the unit cell contents down the $a$-axis highlighting the stacking of layers along the $c$-axis. The $\mathrm{C}-\mathrm{H} \cdots \mathrm{Br}$ interactions are represented as purple dashed lines.

\section{Docking studies}

The enzymes used as molecular targets in the docking calculations were human Cathepsins B, K, L and S. Their three-dimensional structures were retrieved from the Protein Data Bank (PDB) [65] and PDBSum [66]. Their pdb codes and the resolution of their X-ray crystal structures are shown in Table 3 .

Tab. 3: Three-dimensional features of the Cathepsins (Cat.) employed in the present study.

\begin{tabular}{c|c|c|c}
\hline Enzyme & PDB code & Resolution & Reference \\
\hline Cat. B & $1 \mathrm{GMY}$ & $1.9 \AA$ & {$[67]$} \\
\hline Cat. K & $1 \mathrm{U} 9 \mathrm{~V}$ & $2.2 \AA$ & {$[68]$} \\
\hline Cat. L & $2 \mathrm{XU} 3$ & $0.9 \AA$ & {$[69]$} \\
\hline Cat. S & $1 \mathrm{MS6}$ & $1.9 \AA$ & {$[70]$} \\
\hline
\end{tabular}

According to Schechter and Berger [71], the protease active sites of the papain family comprises sub-sites that are distinct in each protease and are crucial for their inhibition [37]. Since there is a lack of a complete description in the literature of the Cathepsin K, L and S sub-sites, it was necessary to perform a sequential and structural alignment of Cathepsins $\mathrm{K}, \mathrm{L}$ and $\mathrm{S}$ with the aim of determining the residues comprising their sub-sites; Cathepsin B is well understood in this regard. The alignments were related to

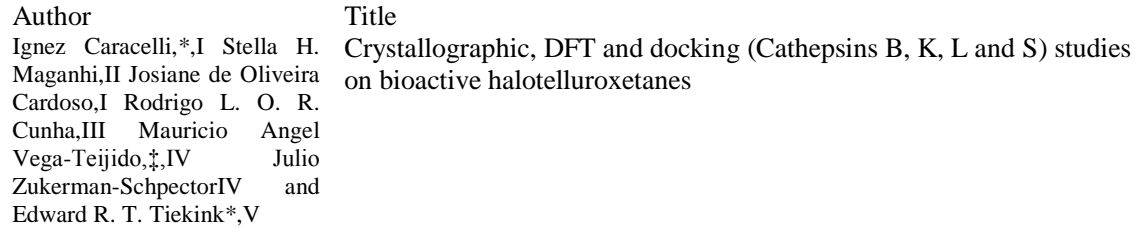


the Cathepsin B residues, since this has the best description of sub-sites, as well as the classical catalytic triad residues of Cathepsins: cysteine, histidine and asparagine.

Experimental observations showed that tellurium(IV) compounds are irreversible inhibitors of cysteine proteases $[28,31,72,73]$. The inhibition occurs due to the formation of a Te(IV)-SG covalent bond between the electrophilic tellurium(IV) centre and the nucleophilic thiol group of the catalytic cysteine via the loss of a leaving group bound to the tellurium atom [31, 32, 47, 48]. According to previous work [47, 48], to create an environment to satisfy the covalent complex hypothesis, the telluriumbound halide, considered the best leaving group in each of 1-4, was removed giving the corresponding cations $\mathbf{1}^{\prime}, \mathbf{2}^{\prime}, \mathbf{3}^{\prime}$ and $\mathbf{4}^{\prime}$, respectively and these were used to simulate the formation of the Cathepsin-telluroxetane complexes in the enzymes listed in Table 3. It should be noted that after removing the tellurium-bonded halide $\mathbf{3}^{\prime}$ is equivalent to $\mathbf{4}^{\prime}$ so only $\mathbf{3}^{\prime}$ was used for the final stages of the docking studies, i.e. when the Te-SG covalent bond is formed. Docking simulations were performed for each $\mathrm{Ca}$ thepsin based on the formation of a covalent complex involving the E- and $\mathrm{Z}$-isomers of each telluroxetane with the sulphur of the catalytic cysteine residue.

\section{Structural and sequence alignments}

It is well established that a potent and specific inhibitor against Cathepsins will have structural features that, besides interacting with the catalytic triad, will interact with regions called sub-sites that are responsible of the protease specificity [74] contributing to its stabilisation in that position. Table 4 summarises some sub-sites that according to the literature should be occupied for an efficient and specific inhibition. Herein, a brief overview of the relevant sub-sites in each studied Cathepsin is presented. It is important to highlight that in all cases the occupation of the S1 sub-site is required for inhibition, as this is the place where the catalytic thiol is located.

Tab. 4: Sub-sites that should be occupied to achieve the most efficient inhibition of the studied Cathepsins (Cat.).

\begin{tabular}{c|c|c}
\hline Enzyme & Sub-sites & References \\
\hline Cat. B & S1, S1', S2' & {$[75]$} \\
\hline Cat. K & S1, S2, S3, S1' & {$[76]$} \\
\hline Cat. L & S1, S2, S3, S1' & {$[77]$} \\
\hline Cat. S & S1, S2, S3 & {$[78-80]$} \\
\hline
\end{tabular}

From the structural and sequential alignment, it was possible to observe a significant structural similarity between the studied Cathepsins. As can be seen in Figure 6, there is a good overlap of $\alpha$-helices and $\beta$-sheets, the difference being mainly in the loops of different conformations and sizes. Moreover, the amino acids sub-sites composition of Cathepsins B, K, L and $\mathrm{S}$ were determined, as shown in Table 5.

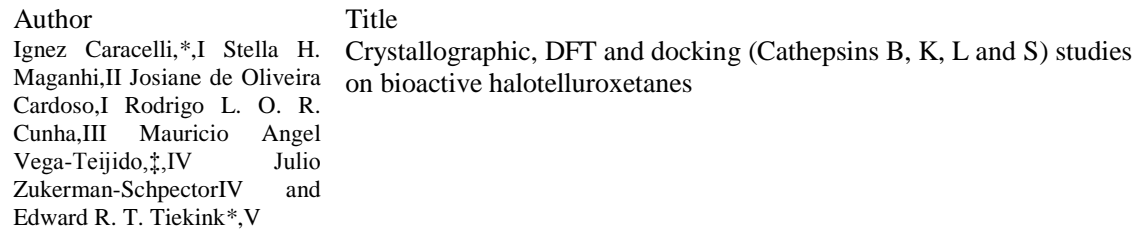




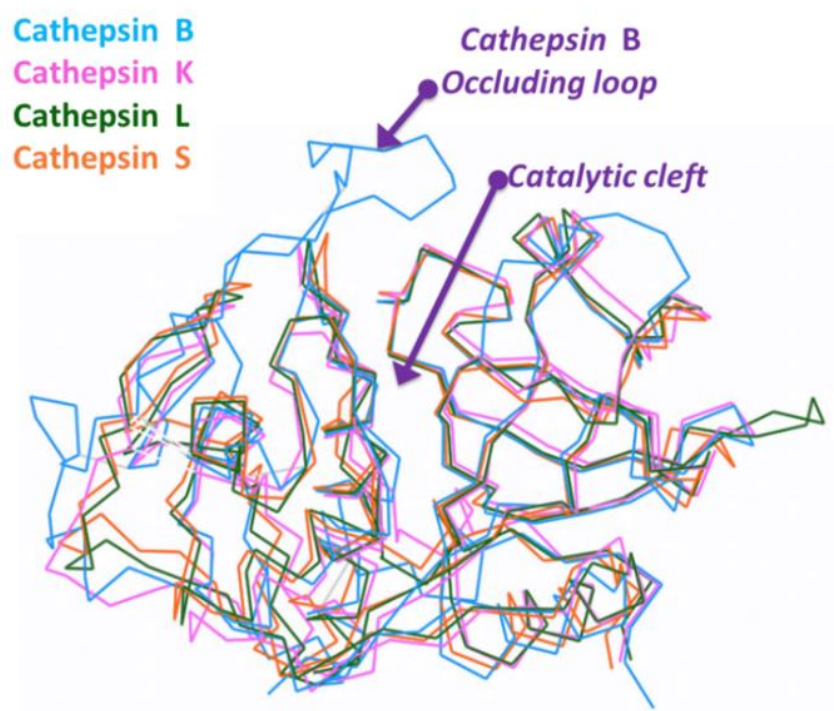

Fig. 6: Diagram showing the overlap, using the backbone trace line, of the threedimensional structures of Cathepsins B (blue), K (pink), L (green) and S (orange) The Cathepsin B occluding loop is shown as this region gives exopeptidase activity to this protease, which is the only one that acts as an endo-/exo-peptidase [81-83].

Tab. 5: A summary of the residues that comprise the studied Cathepsin (Cat.) sub-sites and colour code for the sub-sites

\begin{tabular}{|c|c|c|c|c|}
\hline $\begin{array}{l}\text { Sub- } \\
\text { site }\end{array}$ & Cat. B & Cat. K & Cat. L & Cat. S \\
\hline S3 & Tyr75 & $\begin{array}{l}\text { Tyr67 } \\
\text { Glu59 } \\
\text { Asp61 }\end{array}$ & $\begin{array}{c}\text { Gly61 } \\
\text { Glu63 } \\
\text { Asn66 } \\
\text { Gly67 } \\
\text { Leu69 }\end{array}$ & $\begin{array}{l}\text { Gly62 } \\
\text { Lys64 } \\
\text { Phe70 }\end{array}$ \\
\hline S2 & $\begin{array}{c}\text { Pro76 } \\
\text { Ala173 } \\
\text { Ala200 } \\
\text { Glu245 }\end{array}$ & $\begin{array}{l}\text { Met68 } \\
\text { Ala134 } \\
\text { Ala163 } \\
\text { Leu209 }\end{array}$ & $\begin{array}{l}\text { Met70 } \\
\text { Ala135 } \\
\text { Asp160 } \\
\text { Met161 } \\
\text { Gly164 } \\
\text { Ala214 }\end{array}$ & $\begin{array}{l}\text { Met71 } \\
\text { Gly137 } \\
\text { Val162 } \\
\text { Asn163 } \\
\text { Gly165 } \\
\text { Phe211 }\end{array}$ \\
\hline S1 & $\begin{array}{c}\text { Gln23 } \\
\text { Gly27 } \\
\text { Cys29 } \\
\text { Gly74 } \\
\text { Gly198 }\end{array}$ & $\begin{array}{c}\text { Gly23 } \\
\text { Ser24 } \\
\text { Cys25 } \\
\text { Gly64 } \\
\text { Gly65 } \\
\text { Gly66 } \\
\text { Asn161 }\end{array}$ & $\begin{array}{c}\text { Gln19 } \\
\text { Gly23 } \\
\text { Ser24 } \\
\text { Cys25 } \\
\text { Gly68 }\end{array}$ & $\begin{array}{l}\text { Gln19 } \\
\text { Cys22 } \\
\text { Gly23 } \\
\text { Cys25 } \\
\text { Cys66 } \\
\text { Asn67 } \\
\text { Gly68 } \\
\text { Gly69 }\end{array}$ \\
\hline S1' & $\begin{array}{l}\text { Val176 } \\
\text { Phe180 } \\
\text { Leu181 } \\
\text { Met196 } \\
\text { His199 }\end{array}$ & $\begin{array}{l}\text { Ala137 } \\
\text { Gln143 } \\
\text { Phe142 } \\
\text { His162 }\end{array}$ & $\begin{array}{l}\text { Ala138 } \\
\text { Gly139 } \\
\text { Ser142 } \\
\text { Leu144 } \\
\text { His163 } \\
\text { Trp189 }\end{array}$ & $\begin{array}{l}\text { Ala140 } \\
\text { Arg141 } \\
\text { Phe145 } \\
\text { Phe146 } \\
\text { His164 } \\
\text { Trp186 }\end{array}$ \\
\hline
\end{tabular}

Ignez Caracelli,*,I Stella H. Crystallographic, DFT and docking (Cathepsins B, K, L and S) studies Maganhi,II Josiane de Oliveira on bioactive halotelluroxetanes 


\begin{tabular}{ll|c|c|c}
\hline \multirow{3}{*}{ S2' } & Gly24 & Gln19 & Gln19 & Gln19 \\
& His110 & Gly20 & Gly20 & Gly20 \\
& His111 & Trp184 & Asp162 & Trp186 \\
& Gly121 & & & \\
& Trp221 & & & \\
& & & & \\
\hline
\end{tabular}

\section{Analyses of the Cathepsin-ligand complexes}

Ligands $\mathbf{1}^{\prime}, \mathbf{2}^{\prime}$ and $\mathbf{4}^{\prime}$ were evaluated in both their E- and Z-configurations with all Cathepsins. The ligands with the six-membered alkane ring showed the best results for covalent bond formation rather than $\mathbf{1}$ ' that has a seven-membered alkane ring, a result indicating steric hindrance associated with the increasing size of the ring.

For each study, docking results were first analysed by clustering similar poses. Within each group, the pose with the highest score and the shortest Te-SG distance was chosen, Table 6, then the interactions of the ligandenzyme complex were analysed.

\begin{tabular}{|c|c|c|c|c|c|c|c|c|}
\hline \multirow{2}{*}{$\frac{\mathbf{E}}{\text { Ligand }}$} & \multicolumn{2}{|c|}{ Cat. S } & \multicolumn{2}{|c|}{ Cat. $\mathrm{K}$} & \multicolumn{2}{|c|}{ Cat. L } & \multicolumn{2}{|c|}{ Cat. B } \\
\hline & $\begin{array}{c}\text { Te-SG } \\
(\AA)\end{array}$ & $\begin{array}{c}\text { score } \\
(\mathrm{kcal} / \mathrm{mol})\end{array}$ & $\begin{array}{c}\text { Te-SG } \\
(\AA)\end{array}$ & $\begin{array}{c}\text { score } \\
(\mathrm{kcal} / \mathrm{mol})\end{array}$ & $\begin{array}{c}\text { Te-SG } \\
(\AA)\end{array}$ & $\begin{array}{c}\text { score } \\
(\mathrm{kcal} / \mathrm{mol})\end{array}$ & $\begin{array}{c}\text { Te-SG } \\
(\AA)\end{array}$ & $\begin{array}{c}\text { score } \\
(\mathrm{kcal} / \mathrm{mol})\end{array}$ \\
\hline $1^{\prime}$ & 3.5 & 41.1 & 3.4 & 42.9 & 3.5 & 41.1 & 3.5 & 42.6 \\
\hline $2^{\prime}$ & 3.0 & 48.0 & 3.0 & 43.1 & 2.9 & 42.4 & 3.0 & 40.0 \\
\hline $3^{\prime}$ & 2.9 & 47.5 & 3.1 & 43.5 & 3.1 & 42.2 & 3.0 & 43.2 \\
\hline $\mathbf{Z}$ & \multicolumn{2}{|c|}{ Cat. S } & \multicolumn{2}{|c|}{ Cat. $\mathbf{K}$} & \multicolumn{2}{|c|}{ Cat. L } & \multicolumn{2}{|c|}{ Cat. B } \\
\hline Ligand & $\begin{array}{l}\mathrm{Te}- \\
\mathrm{SG} \\
(\AA) \\
\end{array}$ & $\begin{array}{c}\text { score } \\
(\mathrm{kcal} / \mathrm{mol})\end{array}$ & $\begin{array}{c}\mathrm{Te}-\mathrm{SG} \\
(\AA)\end{array}$ & $\begin{array}{c}\text { score } \\
(\mathrm{kcal} / \mathrm{mol})\end{array}$ & $\begin{array}{c}\text { Te-SG } \\
(\AA)\end{array}$ & $\begin{array}{c}\text { score } \\
\text { (kcal/mol) }\end{array}$ & $\begin{array}{c}\text { Te-SG } \\
(\AA)\end{array}$ & $\begin{array}{c}\text { score } \\
(\mathrm{kcal} / \mathrm{mol})\end{array}$ \\
\hline $1^{\prime}$ & 3.6 & 41.6 & 2.9 & 33.0 & 3.8 & 34.6 & 3.7 & 31.5 \\
\hline $2^{\prime}$ & 3.4 & 42.3 & 5.4 & 40.7 & 2.9 & 38.2 & 4.3 & 36.1 \\
\hline $3^{\prime}$ & 3.4 & 34.4 & 3.2 & 42.1 & 3.5 & 32.8 & 4.1 & 32.2 \\
\hline
\end{tabular}

The analysis of the docking calculations indicates more favourable results for ligands having an E-configuration rather than $\mathrm{Z}$ (Table 6). For distances Te-SG > $3.2 \AA$, there is no covalent bond formation, which is in agreement with the very poor activity of $\mathbf{1}$ in Cathepsin B, Table 7. Further, as seen from the Supplementary Materials, the docked structures of 1'-3' resemble very closely those observed in the molecular crystals structures with the obvious exception of the missing halide. This vindicates the assertion that GOLD [61, 62] indeed takes into account stereochemically-active lone-pairs of electrons as found in 1'-3'.

Tab. 7: Second-order rate constant values $\left(10^{3} \mathrm{M}^{-1} \mathrm{~s}^{-1}\right)$ for the inhibition of the studies Cathepsins (Cat.) by the telluroxetanes 1-3 [31, 32].

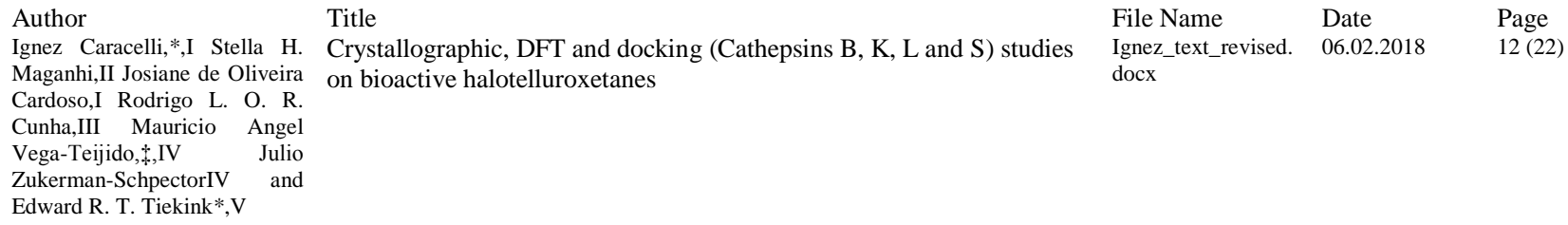

File Name Date Page Ignez_text_revised. $\quad 06.02 .2018 \quad 12(22)$ docx 


\begin{tabular}{ccccc}
\hline Compound & Cat. S & Cat. K & Cat. L & Cat. B \\
\hline $\mathbf{1}$ & - & - & - & $1.6 \pm 0.1$ \\
\hline $\mathbf{2}$ & $196 \pm 17$ & $1200 \pm 320$ & $170 \pm 12$ & $36.0 \pm 3.2$ \\
\hline $\mathbf{3}$ & $8940 \pm 470$ & $420 \pm 31$ & $650 \pm 51$ & $7.7 \pm 0.9$ \\
\hline
\end{tabular}

The docking results for $\mathbf{2}^{\prime}$ and $\mathbf{3}^{\prime}\left(=\mathbf{4}^{\prime}\right)$ exhibit relatively small differences indicating that the halide has little influence on the activity. In Figure 7 , the main amino acids residues interacting with the ligand molecules are indicated with further details given in the captions to Figs 8-11.

\section{Label S2' S1' S1 S2 S3}
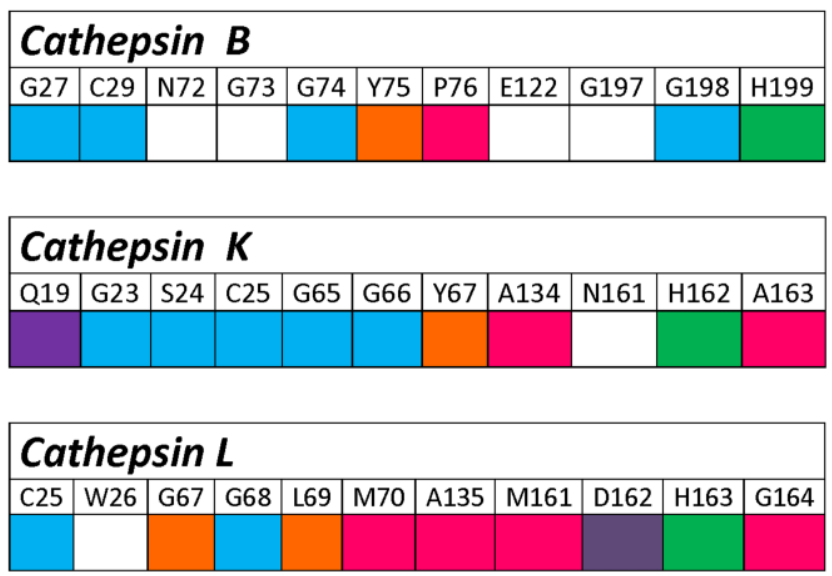

\section{Cathepsin S}

\begin{tabular}{|l|l|l|l|l|l|l|l|l|l|l|}
\hline C25 & G68 & G69 & F70 & M71 & G137 & R141 & V162 & N163 & H164 & G165 \\
\hline
\end{tabular}

Fig. 7: A summary of the main interactions of ligands $2^{\prime}$ and $3^{\prime}$ in the studied Cathepsins. Colours follow that of Table 5, those not coloured refer to interactions not involving any specific subsite.

In the following, the surface representation of the best pose together with some interactions for ligands $\mathbf{2}^{\prime}$ and $\mathbf{3}^{\prime}$ in the four Cathepsins will be presented. The sub-sites colours for Figures 8-11 are defined as in Table 5.

In Figure 8a, the surface representation of the best pose of ligands 2 ' and $\mathbf{3}^{\prime}$ in Cathepsin $\mathrm{B}$ and in Figure $8 \mathrm{~b}$ highlights the $\mathrm{C}-\mathrm{O} \cdots \pi$ interaction with Gly74 of sub-site S1 and the C-O -.Te interaction with Gly27.

Ignez Caracelli,,,I Stella H. Crystallographic, DFT and docking (Cathepsins B, K, L and S) studies Maganhi,II Josiane de Oliveira on bioactive halotelluroxetanes Cardoso,I Rodrigo L. O. R.

Cunha,III Mauricio Angel

Vega-Teijido,\$,IV Julio

Zukerman-SchpectorIV and

Edward R. T. Tiekink*,V 


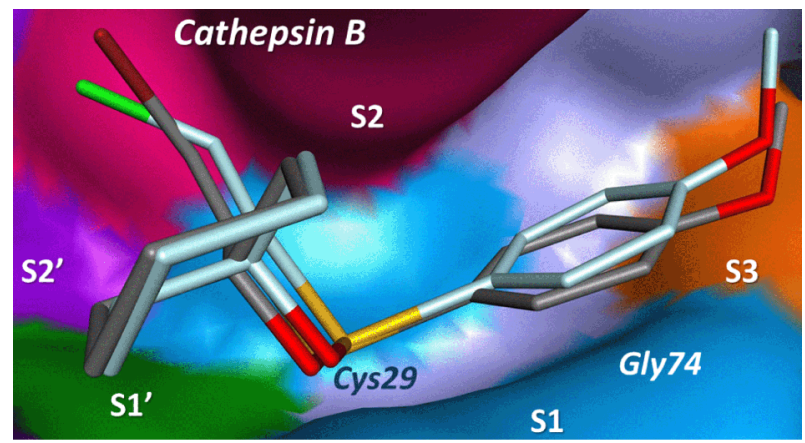

(a)
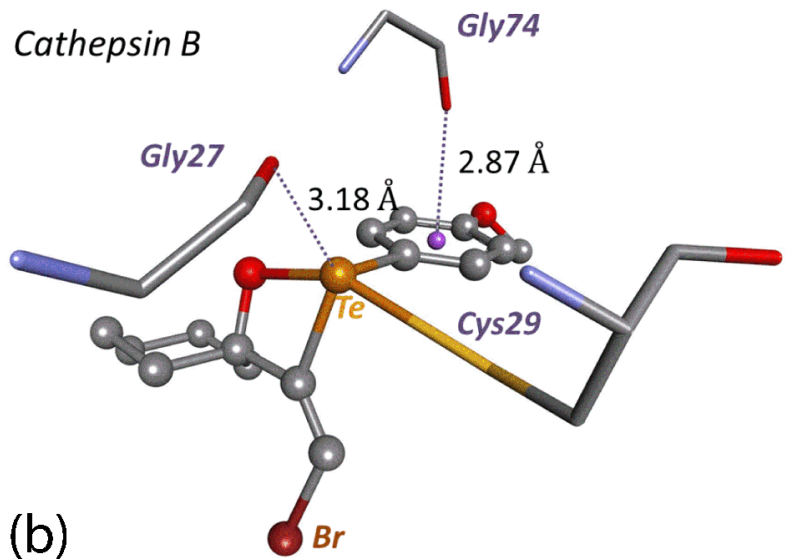

Fig. 8: (a) Surface representation of ligands $\mathbf{2}^{\prime}$ and $\mathbf{3}^{\prime}$ in the E-configuration in Cathepsin B and (b) two interactions of $\mathbf{3}^{\prime}$ with residues of sub-site S1.

As indicated in Table 4, a good and specific Cathepsin B inhibitor should occupy the S1' and S2' sub-sites, especially the S2' sub-site which comprises the occluding loop that was shown to be very important for inhibition activity $[48,75]$. The docking results, shown in Figure 7 for 2 ' and 3' in Cathepsin B indicate that these do not occupy the S2' sub-site and this may explain the fact of their very low binding affinity values for this protease, as indicated in Table 7. 


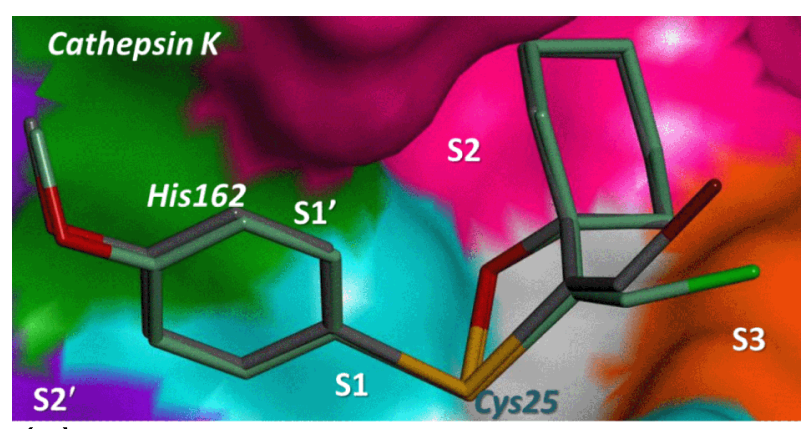

(a)

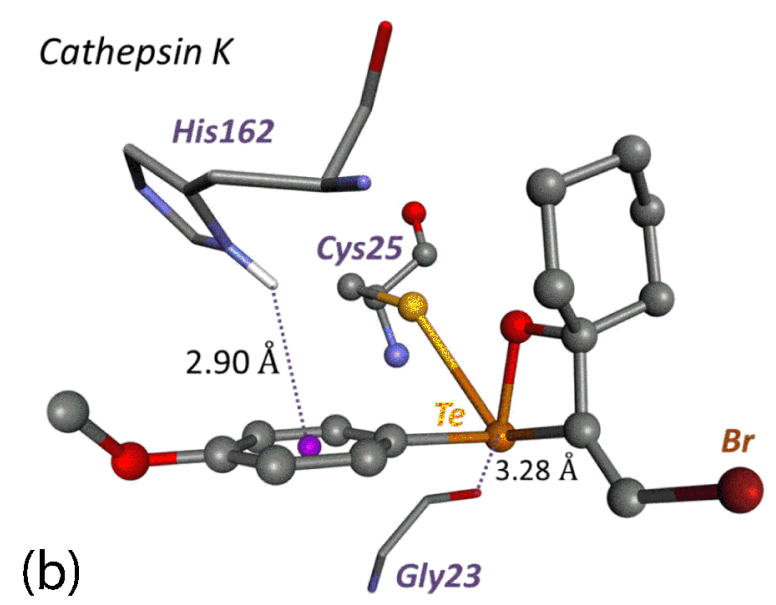

Fig. 9: (a) Surface representation of ligands $\mathbf{2}^{\prime}$ and $\mathbf{3}^{\prime}$ in the E-configuration in Cathepsin K and (b) two interactions of $\mathbf{3}^{\prime}$ with residues of sub-sites S1 and S1'.

The docking studies in Cathepsin $\mathrm{K}$ shows that the telluroxetanes are positioned in the active site and occupy the S1, S1' and S2 sub-sites (Figures 7 and 9). These results explain the good Cathepsin $\mathrm{K}$ inhibition values of $\mathbf{2}$ and $\mathbf{3}$ (Table 7). Figure 9a shows the surface representation of the best poses of ligands 2' and $\mathbf{3}^{\prime}$ in Cathepsin $\mathrm{K}$ and in Figure $9 \mathrm{~b}$ are shown two of the interactions involving $3^{\prime}$ : a $\mathrm{C}-\mathrm{H} \cdots \pi$ interaction with His 162 from the S1' sub-site and a Te $\cdots \mathrm{O}$ contact with Gly23 of the S1 sub-site.

\footnotetext{
Author Title

Ignez Caracelli, ${ }^{*}$, I Stella H. Crystallographic, DFT and docking (Cathepsins B, K, L and S) studies

Maganhi,II Josiane de Oliveira on bioactive halotelluroxetanes 


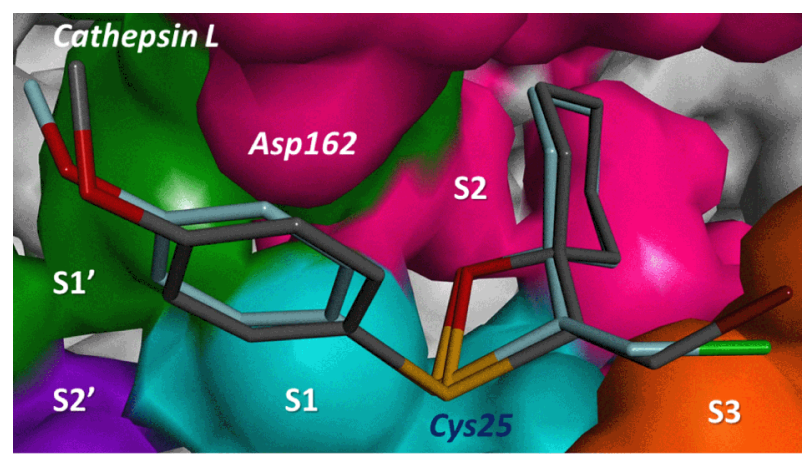

(a)

\section{Cathepsin L}

(b)

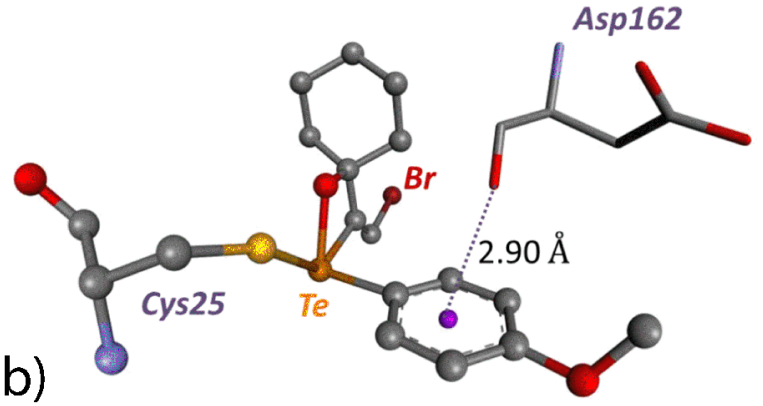

Fig. 10: (a) Surface representation of ligands $2^{\prime}$ and $3^{\prime}$ in the E-configuration in Cathepsin $\mathrm{L}$ and (b) the $\mathrm{C}-\mathrm{O} \cdots \pi$ interaction of $\mathbf{3}^{\prime}$ with a residue of sub-site $\mathrm{S} 2$.

In Cathepsin L, the telluroxetane ligands occupy the S1, S1', S2 and S3 sub-sites (Figures 7 and 10), which can explain their relative good inhibition activity (Table 7). In this case, the shortest distance to the tellurium(IV) atom involves the oxygen of Gly68, i.e. at $3.92 \AA$.

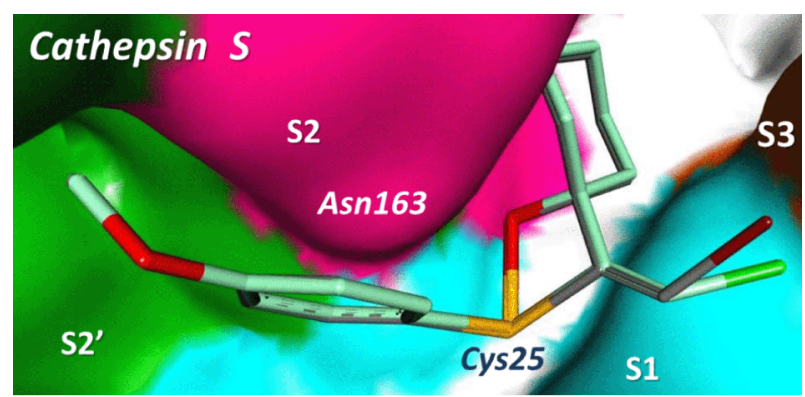

(a)

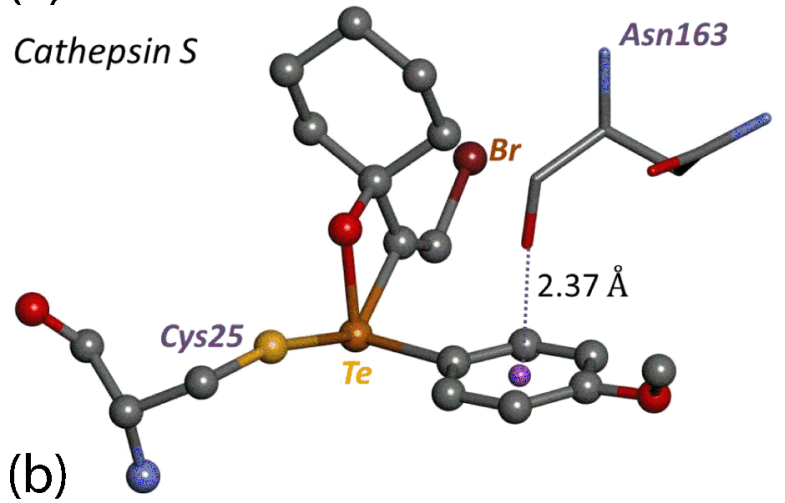

Fig. 11: Surface representation of ligands $\mathbf{2}^{\prime}$ and $\mathbf{3}^{\prime}$ in the E-configuration in Cathepsin $\mathrm{S}$ and (b) $\mathrm{C}-\mathrm{O} \cdots \pi$ interaction of $\mathbf{3}^{\prime}$ with a residue of sub-site $\mathrm{S} 2$.

Author Title

File Name Date Page

Ignez Caracelli, ${ }^{*}$, I Stella H. Crystallographic, DFT and docking (Cathepsins B, K, L and S) studies

Maganhi,II Josiane de Oliveira on bioactive halotelluroxetanes

Ignez_text_revised. $06.02 .2018 \quad 16(22)$

Cardoso,I Rodrigo L. O. R.

Cunha,III Mauricio Angel

Vega-Teijido, $\$$,IV Julio

Zukerman-SchpectorIV and

Edward R. T. Tiekink*,V 
As seen in Figures 7 and 11a for Cathepsin S, ligands $\mathbf{2}^{\prime}$ and $\mathbf{3}^{\prime}$ are positioned in the S1, S1', S2 and S3 sub-sites, with the cyclohexane moiety located in the $\mathrm{S} 2 \mathrm{sub}$-site. In this case, the shortest $\mathrm{Te} \cdot \cdots \mathrm{O}$ distance is from Gly69 at $3.93 \AA$. Furthermore, the occupation of the S2 and S3 sub-sites are described as crucial for Cathepsin S selectivity with respect to the other Cathepsins, especially Cathepsin K [78]. These results are in good agreement with the inhibitory activity observed for $\mathbf{2}$ and $\mathbf{3}$ as shown in Table 7.

\section{Overview}

The analysis of the docking calculations indicates more favourable results for ligands having an E-configuration rather than $\mathrm{Z}$.

In each Cathepsin, ligands $\mathbf{2}^{\prime}$ and $\mathbf{3}^{\prime}$ ' have very similar binding modes, i.e. they form a Te-SG covalent bond and the phenyl ring makes a $\mathrm{C}-\mathrm{O} \ldots \pi$ interaction. The other interactions with other residues of different sub-sites are specific for each Cathepsin.

It is worth pointing out the different behaviour of the organic-ligandbound halides. In Cathepsins B and $\mathrm{K}$, these halides are not involved in any kind of interaction, whereas in Cathepsin L the Gly68 residue is involved in $\mathrm{C}-\mathrm{O} \cdots \mathrm{Cl}$ halogen bond $(2.65 \AA)$ to the chloride atom of ligand 2 ', and with the bromide atom of ligand 3', at $3.50 \AA$, Figure 12. In Cathepsin $\mathrm{S}$, the halides are involved in interactions with the phenyl ring of Phe70, the chloride forming a delocalised interaction and the bromine forming a localised interaction; see Figure 13.
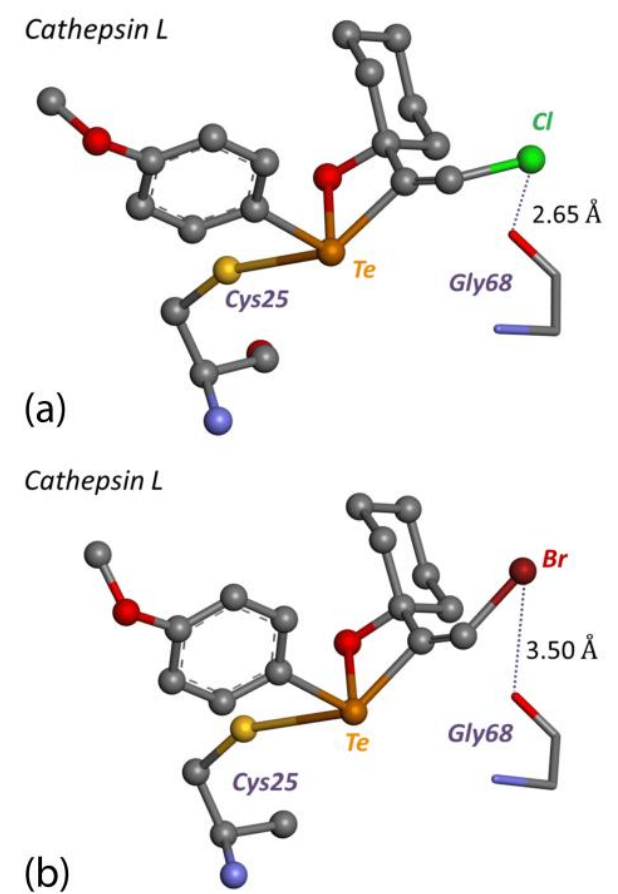

Fig. 12: (a) An image of the $\mathrm{Cl}^{\cdots} \mathrm{O}$ halogen-bond formed by ligand $2^{\prime}$ and the Gly68 residue in Cathepsin $\mathrm{L}$ and (b) an analogous $\mathrm{Br}^{\cdots} \mathrm{O}$ interaction between $\mathbf{3}^{\prime}$ and Gly68.

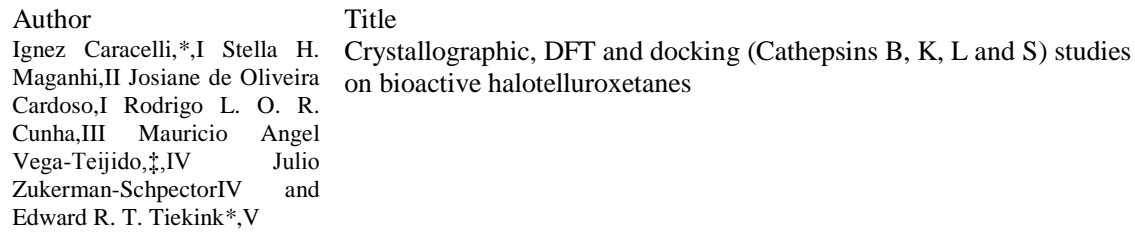

File Name Date Page Ignez_text_revised. $\quad 06.02 .2018 \quad 17(22)$ docx 
Another interesting observation is the fact that when the halides are not involved in interactions as is the case with Cathepsins B and $\mathrm{K}$, the secondorder rate constant for inhibition for each complex is greater for the chloride-containing compound. Whereas with Cathepsins S and L, where the halides are involved in the interactions, shown in Figures 12 and 13, the relationship between the second-order rate constants is the opposite.
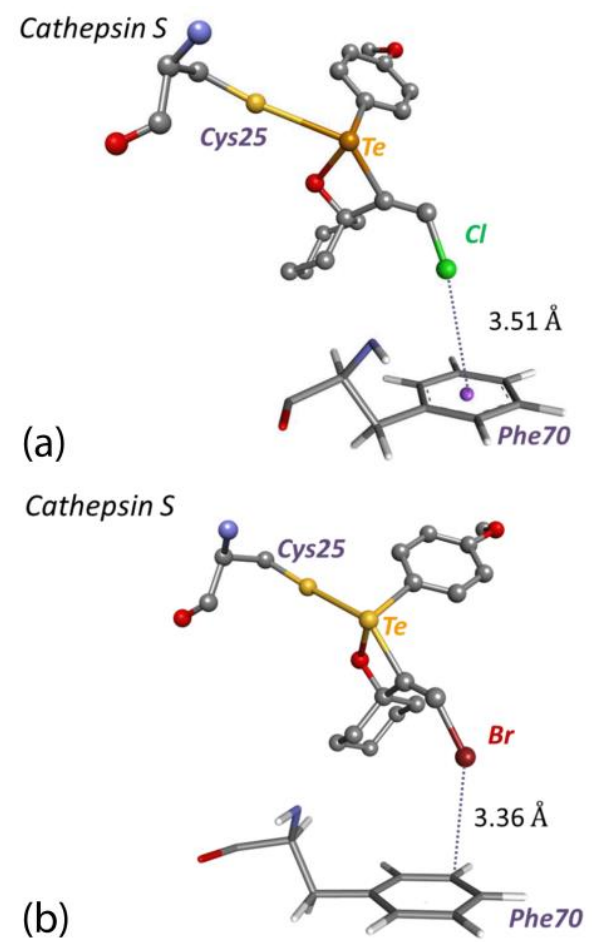

Fig. 13: (a) An image of the delocalised $\mathrm{Cl}^{\cdots} \pi$ interaction formed by ligand $\mathbf{2}^{\prime}$ with the ring in Phe 70 in Cathepsin $\mathrm{S}$ and (b) an analogous but localised $\mathrm{Br}^{\cdots} \pi$ interaction between $\mathbf{3}^{\prime}$ and Phe70.

\section{Conclusions}

Biologically active tellurium/organotellurium compounds such as AS-101 and 1-4 are known to inhibit biologically important substrates such as Cathepsins. For 1-4, there is loss of the tellurium-bound halide which enables the formation of covalent Te-SG bonds in most cases; the lack of a strong bond in the case of $\mathbf{1}^{\prime}$ correlates with its relative lack of activity. Detailed docking studies confirms the relative importance of an E- over a Z-configuration in all cases. All Cathepsins studied feature a $\mathrm{C}-\mathrm{O} \cdots \pi$ interaction involving a phenyl ring for ligands $2^{\prime}$ and $3^{\prime}\left(=4^{\prime}\right)$. Interestingly, the nature of organic residue-bound halide has no influence on the binding mode in Cathepsins B and K. By contrast, in Cathepsin L these atoms are involved in $\mathrm{C}-\mathrm{O} \cdots \mathrm{X}$ halogen bonds, whereas in Cathepsin $\mathrm{S}$, these halides form delocalised (chloride) and localised (bromide) interactions. This differential behaviour provides hope for the rational design of molecules to target specific receptor sites in Cathepsins.

In terms of future work, this study demonstrates the efficacy of E- over Zconfigurations for the investigated tellurooxetanes, at least for Cathepsins $\mathrm{B}, \mathrm{K}, \mathrm{L}$ and $\mathrm{S}$. Thus, the search for more promising inhibitors suggests the need of diastereoselective synthesis. Also, structural modifications are required so that metabolites of new test compounds can occupy subsite S3 of the active site of Cathepsin $\mathrm{K}$, and should occupy all extensions of the active site of cathepsin L. Moreover, the poor inhibition activity and the docking results in Cathepsin B shows the need for chemical modifications

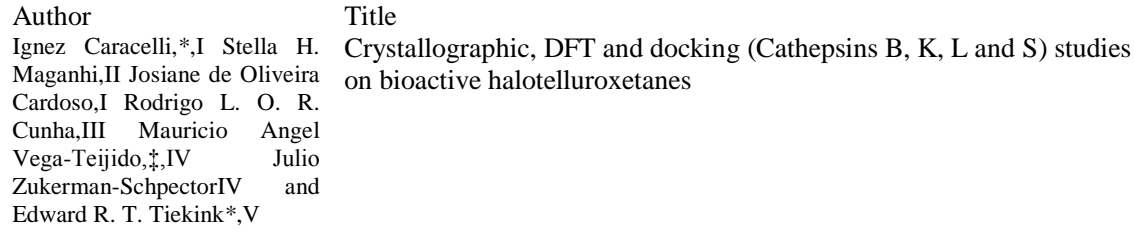


that will enable interaction with the $\mathrm{S} 1^{\prime}$ and $\mathrm{S} 2$ ' sites in the receptor site of Cathepsin B. Finally, for Cathepsin S, it seems important that more interactions are required with subsites $\mathrm{S} 2$ and $\mathrm{S} 3$.

Acknowledgements: The support of the Brazilian agencies the National Council for Scientific and Technological Development (CNPq-308480/2016-3 to IC, 305626/2013-2 to JZS), São Paulo Research Foundation (FAPESP-12/22524-9 to SHM) and the Coordination for the Improvement of Higher Education Personnel (CAPES) are acknowledged.

\section{References}

[1] J. T. Rotruck, A. L. Pope, H. E. Ganther, A. B. Swanson, D. G. Hafeman, W. G. Hoekstra, Science 1973, 179, 588.

[2] L. Flohé, W. A. Günzler, H. H. Schock, FEBS Lett. 1973, $32,132$.

[3] A. Böck, K. Forchhammer, J. Heider, J. Leinfelder, G. Sawers, B. Veprek, F. Zinoni, Mol. Microbiol. 1991, 5, 515.

[4] T. C. Stadtman, Ann. Rev. Biochem. 1996, 65, 83.

[5] J. Rafique, R. F. S. Canto, S. Saba, F. A. R. Barbosa, A. L. Braga, Curr. Org. Chem. 2016, 20, 166.

[6] D. Mániková, L. M. Letavayová, D. Vlasáková, P. Košík, E. C. Estevam, M. J. Nasim, M. Gruhlke, A. Slusarenko, T. Burkholz, C. Jacob, M. Chovanec, Molecules 2014, 19, 12258.

[7] L. Piovan, P. Milani, M. S. Silva, P. G. Moraes, M. Demasi, L. H. Andrade, Eur. J. Med. Chem. 2014, 73, 280.

[8] S. Shaaban, F. Sasse, T. Burkholz, C. Jacob, Bioorg. Med. Chem. Lett. 2014, 22, 3610.

[9] J. P. Johnpeter, G. Gupta, J. M. Kumar, Srinivas, G. N. Nagesh, B. Therrien, Inorg. Chem. 2013, 52, 13663.

[10] E. R. T. Tiekink, Dalton Trans. 2012, 41, 6390.

[11] C. W. Nogueira, G. W. Zeni, J. B. Rocha, Chem. Rev. 2004, 104,6255 .

[12] L. Orian, S. Toppo, Free Radical Biol. Med. 2014, 66, 65.

[13] G. Halpert, B. Sredni, Autoimmun. Rev. 2014, 13, 1230.

[14] R. H Revanna, R. K. Panchangam, U. Bhanu, S. Doddavenkatanna, J. Braz. Chem. Soc. 2016, 27, 1157.

[15] S. Kumar, L. Engman, L. Valgimigli, R. Amorati, M. G. Fumo, G. F. Pedulli, J. Org. Chem. 2007, 72, 6046.

[16] X. Ren, Y. Xue, J. Liu, K. Zhang, J. Zheng, G. Luo, C. Guo, Y. Mu, J. Shen, ChemBioChem 2002, 3, 356.

[17] S. E. C. Maluf, P. M. S. Melo, F. P. Varotti, M. L. Gazarini, R. L. O. R. Cunha, A. K. Carmona, Parasitology Internat. 2016, 65, 20.

[18] I. A. S. Pimentel, C. S. Paladi, S. Katz, W. A. S. Júdice, R. L. O. R. Cunha, C. L. Barbiéri, PLoS ONE 2012, 7, e48780.

[19] M. Brodsky, G. Halpert, M. Albeck, B. Sredni, J. Inflammation, 2010, 7, 3.

[20] D. Ling, B. Liu, S. Jawad, I. A. Thompson, C. N. Nagineni, J. Dailey, J. Chien, B. Sredni, R. B. Nussenblatt, $\mathrm{Br}$ J Ophthalmol. 2013, 97, 934.

[21] D. S. Avila, D. Colle, P. Gubert, A. S. Palma, G. Puntel, F. Manarin, S. Noremberg, P. C. Nascimento, M. Aschner, J. B. Rocha, F. A. Soares, Toxicol. Sci. 2010, 115, 194.

[22] B. Sredni, R. Geffen-Aricha, W. Duan, M. Albeck, F. Shalit, H. M. Lander, N. Kinor, O. Sagi, A. Albeck, S. Yosef, M. Brodsky, D. Sredni-Kenigsbuch, T. Sonino, D. L. Longo, M. P. Mattson, G. Yadid, G. Faseb J. 2007, 21, 1870.

[23] P. Du, N. E. B. Saidu, J. Intemann, C. Jacob, M. Montenarh, Biochim. Biophys. Acta 2014, 1840, 1808.

[24] H. L. Seng, E. R. T. Tiekink, Appl. Organometal. Chem. 2012, 26, 655 .

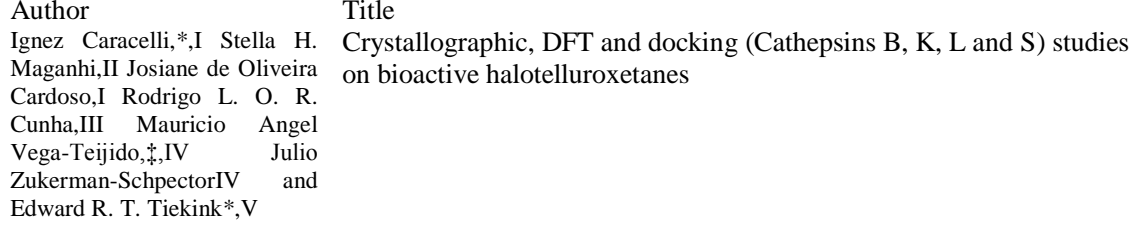


[25] B. Sredni, Semin. Cancer Biol. 2012, 22, 60.

[26] A. Silberman, Y. Kalechman, S. Hirsch, Z. Erlich, B. Sredni, A. Albeck, ChemBioChem 2016, 17, 918.

[27] B. Sredni, R. R. Caspi, A. Klein, Y. Kalechman, Y. Danziger, M. Benyaakov, T. Tamari, F. Shalit, M. Albeck, Nature 1987, 330, 173.

[28] A. Albeck, H. Weitman, B. Sredni, M. Albeck, Inorg. Chem. 1998, 37, 1704.

[29] M. Friedman, I. Bayer, I. Letko, R. Duvdevani, O. ZavaroLevy, B. Ron, M. Albeck, B. Sredni, Br. J. Dermatol. 2009, 160, 403.

[30] L. Kalich-Philosoph, H. Roness, A. Carmely, M. FishelBartal, H. Ligumsky, S. Paglin, I. Wolf, H. Kanety, B. Sredni, D. Meirow, Sci. Transl. Med. 2013, 5, 185.

[31] R. L. O. R. Cunha, M. E. Urano, J. R. Chagas, P. C. Almeida, C. Bincoletto, I. L. S. Tersariol, J. V. Comasseto, Bioorg. Med. Chem. Lett. 2005, 15, 755.

[32] R. L. O. R. Cunha, I. E. Gouvea, L. Juliano, L. An. Acad. Bras. Cienc. 2009, 81, 393.

[33] S. Yosef, M. Brodsky, B. Sredni, A. Albeck, M. Albeck, ChemMedChem 2007, 2, 1601.

[34] A. Silberman, M. Albeck, B. Sredni, A. Albeck, Inorg. Chem. 2016, 55, 10847.

[35] Li, Y. Y., Fang, J., Ao, Z. G. Expert Opin. Ther. Pat. 2017, 27, 643.

[36] M. Siklos, M. BenAissa, G.R.J. Thatcher, Acta Pharm. Sin. B 2015, 5, 506.

[37] B. Turk, Nat. Rev. Drug Discov. 2006, 5, 7.

[38] C. Palermo, J. A. Joyce, Trends Pharmacol. Sci. 2008, 29, 22.

[39] V. Turk, V. Stoka, O. Vasilijeva, M. Renko, T. Sun, B. Turk, D. Turk, D. Biochim. Biophys. Acta, Proteins Proteomics, 2012, 1824, 68

[40] J. F. Charles, A. O. Aliprantis, Trends Mol. Med., 2014, 20, 449.

[41] D. Bromme, P. Panwar, S. Turan, Expert Opin. Drug Discov. 2016, 11,457 .

[42] V. Stoka, V. Turk, B. Turk, Ageing Res. Rev. 2016, 32, 22.

[43] M. Z. I. Pranjol, N. Gutowski, M. Hannemann, J. Whatmore, Biomolecules 2015, 5, 3260.

[44] U. Verbovsek, U. C. J. F. Van Noorden, T. T. Lah, Semin Cancer Biol. 2015, 35, 71.

[45] O. C. Olson, J. A. Joyce, Nat. Rev. Cancer 2015, 15, 712.

[46] H. Appelqvist, P. Wäster, K. Kågedal, K. Öllinger, J. Mol. Cell Biol. 2013, 5, 214.

[47] R. L. O. R. Cunha, J. Zukerman-Schpector, I. Caracelli, J. V. Comasseto, J. Organomet. Chem. 2006, 691, 4807.

[48] I. Caracelli, J. Zukerman-Schpector, S. H. Maganhi, H. A. Stefani, R. Guadagnin, E. R. T. Tiekink, J. Braz. Chem. Soc. 2010, 21, 2155

[49] S. D. Ramalho, L. R. F. De'Sousa, L. Nebo, S. H. Maganhi, I. Caracelli, J. Zukerman-Schpector, M. I. S. Lima, M. F. M. Alves, M. F. G. F. Da'Silva, J. B. Fernandes, P. C. Vieira, Chem Biodivers. 2014, 11, 1354.

[50] I. Caracelli, M. Vega-Teijido, J. Zukerman-Schpector, M. H. S. Cezari, J. G. S. Lopes, L. Juliano, P. S. Santos, J. V. Comasseto, R. L. O. R. Cunha, E. R. T. Tiekink, J. Mol. Struct. 2012, 1013, 11 .

[51] I. Caracelli, J. Zukerman-Schpector, L. S. Madureira, S. H. Maganhi, H. A. Stefani, R. C. Guadagnin, E. R. T. Tiekink, Z. Kristallogr. 2016, 231, 321.

[52] J. V. Comasseto, H. A. Stefani, A. Chieffi, J. ZukermanSchpector, Organometallics 1991, 10, 845.

[53] CAD4 Express Software. Enraf-Nonius, Delft, The Netherlands, 1994.

\footnotetext{
Author Title

Ignez Caracelli, *,I Stella H. Crystallographic, DFT and docking (Cathepsins B, K, L and S) studies

Maganhi,II Josiane de Oliveira on bioactive halotelluroxetanes

Cardoso,I Rodrigo L. O. R.

Cunha,III Mauricio Angel

Vega-Teijido,

Zukerman-SchpectorIV and

Edward R. T. Tiekink*,V
} 
[54] XCAD4 - CAD4 Data Reduction. Harms, K. and Wocadlo, S. XCAD-4. Program for Processing CAD-4 Diffractometer Data. University of Marburg, Germany, 1995.

[55] A. Altomare, G. Cascarano, C. Giacovazzo, A. Guagliardi, J. Appl. Crystallogr. 1993, 26, 343.

[56] G. M. Sheldrick, Acta Crystallogr. A 2008, 64, 112

[57] L. J. Farrugia, J. Appl. Crystallogr. 2012, 45, 849.

[58] A. L. Spek, J. Appl. Crystallogr. 2003, 36, 7.

[59] K. Brandenburg, DIAMOND. Crystal Impact GbR, Bonn, Germany, 2006.

[60] HyperChem(TM) Professional 7.51, Hypercube, Inc, 1115 NW $4^{\text {th }}$ Street, Gainsville, Florida 32601, USA, 2015.

[61] G. Jones, P. Willett, R. C. Glen, A. R. Leach, R. Taylor, J. Mol. Biol. 1997, 267, 727.

[62] G. Jones, P. Willett, R. C. Glen, J. Mol. Biol. 1995, 245, 43.

[63] Accelrys DS Visualizer v3.5 (http://accelrys.com/).

[64] E. R. T. Tiekink, Coord. Chem. Rev. 2017, 345, 209.

[65] PDB: http://www.rcsb.org/pdb/home/home.do

[66] PDBSum: http://www.ebi.ac.uk/pdbsum/

[67] P. D. Greenspan, K. L. Clark, R. A. Tommasi, S. D. Cowen, L. W. Mcquire, D. L. Farley, J. H. Duzer, R. L. Goldberg, H. Zhou, Z. Du, J. J. Fitt, D. E. Coppa, Z. Fang, W. Macchia, L. Zhu, M. P. Capparelli, R. Goldstein, A. M. Wigg, J. R. Dougthy, R. S. Bohacek, A. K. Knap, J. Med. Chem. 2001, $44,4524$.

[68] E. Altmann, S. W. Cowan-Jacob, M. Missbach, J. Med. Chem. 2004, 47, 5833 .

[69] L. A. Hardegger, B. Kuhn, B. Spinnler, L. Anselm, R. Ecabert, M. Stihle, B. Gsell, R. Thoma, J. Diez, J. Benz, J. M. Plancher, G. Hartmann, D. W. Banner, W. Haap, F. Diederich, Angew. Chem. Intl. Ed. 2011, 50, 314.

[70] Y. D. Ward, D. S. Thomson, L. L. Frye, C. L. Cywin, T. Morwick, M. J. Emmanuel, R. Zindell, D. McNeil, Y. Bekkali, M. Girardot, M. Hrapchak, M. Deturi, K. Crane, D. White, S. Pav, Y. Wang, M. Hao, C.A. Grygon, M.E. Labadia, D. M. Freeman, W. Davidson, J. L. Hopkins, M. L. Brown, D. M. Spero, J. Med. Chem. 2002, 45, 5471.

[71] I. Schechter, A. Berger, Biochem. Biophys. Res. Commun. 1967, 27, 157.

[72] I. E. Gouvea J. A. N. Santos, F. M. Burlandy, I. L. S. Tersariol, E. E. Da'Silva, M. A. Juliano, L. Juliano, R. L. O. R. Cunha, Biol. Chem. 2011, 392, 587.

[73] L. Piovan, M. F. M. Alves, L. Juliano, D. Brömme, R. L. O. R. Cunha, L. H. Andrade, Bioorg. Med. Chem. Lett. 2011, 19, 2009.

[74] M. Drag, G. S. Salvesen, Nat. Rev. Drug Discovery 2010, 9, 690.

[75] D. Watanabe, A. Yamamoto, K. Tomoo, K. Matsumoto, M. Murata, K. Kitamura, T. Ishida, J. Mol. Biol. 2006, 362, 979.

[76] F. Lecaille, D. Brömme, G. Lalmanach, Biochimie 2008, 90 , 208.

[77] M. C. Myers, P. P. Shah, M. P. Beavers, A. D. Napper, S. L. Diamond, A. B. Smith, D. M. Huryn, Bioorg. Med. Chem. Lett. 2008, 18, 3646.

[78] S. Yesa, C. Lindquist, T. Agback, K. Benkestock, B. Classon, I. Henderson, E. Hewitt, K. Jansson, A. Kallin, D. Sheppard, B. Samuelsson, Bioorg. Med. Chem. 2009, 17, 1307.

[79] D. Brömme, P. R. Bonneau, P. Lachance, A. C. Storer, J. Biol. Chem. 1994, 269, 30238.

[80] T. A. Pauly, T. Sulea, M. Ammirati, J. Sivaraman, D. E. Danley, M. C. Griffor, A. V. Kamath, I.-K. Wang, E. R. Laird, A. P. Seddon, R. Ménard, M. Cygler, V. L. Rath, Biochemistry 2003, 42, 3203.

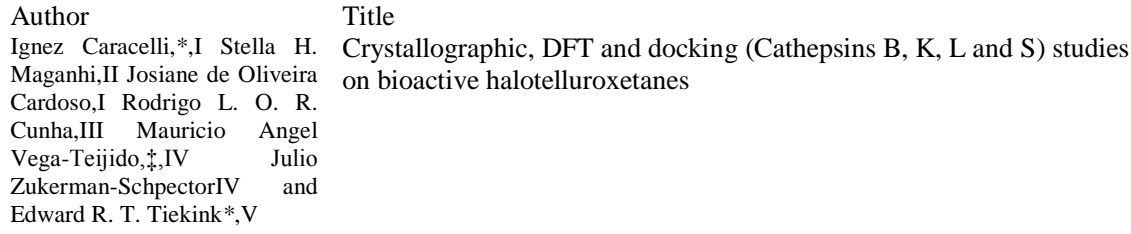


[81] C. Illy, O. Quraishi, J. Wang, E. Purisima, T. Vernet, J. S. Mort, J. Biol. Chem. 1997, 272, 1197.

[82] J. C. Krupa, S. Hasnain, D. K. Nägler, R. Ménard, J. S. Mort, Biochem. J. 2002, 361, 613.

[83] M. Renko, U. Požgan, D. Majera, D. Turk, FEBS J. 2010 $277,4338$.

[84] M. F. M. Alves, L. Puzer, S. S. Cotrin, M. A. Juliano, L. Juliano, D. Brömme, A. K. Carmona, Biochem. J. 2003, 373, 981.

[85] S. F. Chowdhury, L. Joseph, S. Kumar, S. R. Tulsidas, S. Bhat, E. Ziomek, R. Ménard, J. Sivaraman, E. O. Purisima, J. Med. Chem. 2008, 13, 1361. 